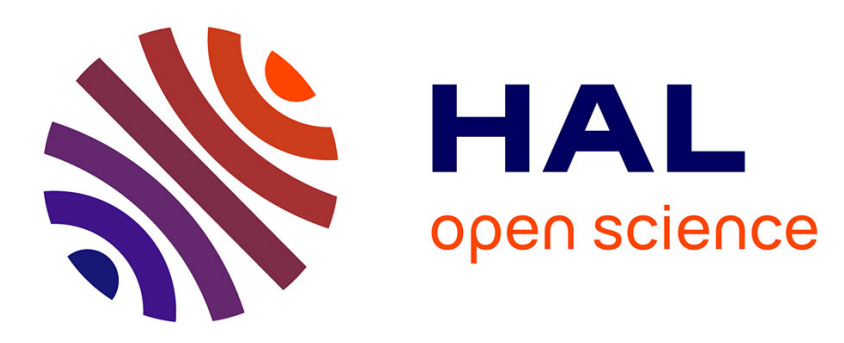

\title{
Impact of vegetation and soil moisture seasonal dynamics on dust emissions over the Sahel
}

Caroline Pierre, G. Bergametti, B. Marticoréna, Éric Mougin, C. Bouet, C. Schmechtig

\section{To cite this version:}

Caroline Pierre, G. Bergametti, B. Marticoréna, Éric Mougin, C. Bouet, et al.. Impact of vegetation and soil moisture seasonal dynamics on dust emissions over the Sahel. Journal of Geophysical Research: Atmospheres, 2012, 117 (D6), pp.n/a-n/a. 10.1029/2011JD016950 . hal-02323555

\section{HAL Id: hal-02323555 \\ https://hal.science/hal-02323555}

Submitted on 21 Oct 2019

HAL is a multi-disciplinary open access archive for the deposit and dissemination of scientific research documents, whether they are published or not. The documents may come from teaching and research institutions in France or abroad, or from public or private research centers.
L'archive ouverte pluridisciplinaire HAL, est destinée au dépôt et à la diffusion de documents scientifiques de niveau recherche, publiés ou non, émanant des établissements d'enseignement et de recherche français ou étrangers, des laboratoires publics ou privés. 


\title{
Impact of vegetation and soil moisture seasonal dynamics on dust emissions over the Sahel
}

\author{
C. Pierre, ${ }^{1,2}$ G. Bergametti, ${ }^{2}$ B. Marticorena, ${ }^{2}$ E. Mougin, ${ }^{1}$ C. Bouet, ${ }^{2,3}$ and C. Schmechtig ${ }^{2}$ \\ Received 29 September 2011; revised 10 February 2012; accepted 13 February 2012; published 30 March 2012.
}

[1] To address the challenging issue of estimating mineral dust emissions from the semi-arid Sahel, a modeling approach is developed by combining two specific models: one dedicated to the simulation of the seasonal herbaceous layer in the Sahel (STEP) and the other to the estimation of dust emissions (MB). The area of interest is the Sahelian belt $\left(12^{\circ} \mathrm{N}-20^{\circ} \mathrm{N}, 20^{\circ} \mathrm{W}-35^{\circ} \mathrm{E}\right)$ and the simulations were performed at a $0.25^{\circ}$ spatial resolution over a 4-year period (2004-2007). The rainfall forcing is provided by a TRMM (Tropical Rainfall Measuring Mission) satellite-derived product; the other meteorological data are ECMWF products. An empirical parameterization is used to estimate the surface roughness and its temporal dynamics according to the characteristics of the simulated vegetation in terms of surface cover and height. Where no vegetation grows, the surface properties are considered as constant in time and are derived from the POLDER-1 satellite measurements. Simulations are constrained step by step by comparisons with observations. Simulated annual dust fluxes emitted from the whole area range from approximately $100 \mathrm{Mt}$ to $400 \mathrm{Mt}$ depending on the year, in good agreement with previous works dealing with Saharan dust emissions. For the fringe where herbaceous vegetation can affect dust emissions, the annual dust emission fluxes range between $0.5 \mathrm{Mt}$ and $20 \mathrm{Mt}$ depending on the year. Inhibition of dust emissions due to the seasonal dynamics of vegetation and surface soil moisture over this fringe varies between $20 \%$ and $35 \%$.

Citation: Pierre, C., G. Bergametti, B. Marticorena, E. Mougin, C. Bouet, and C. Schmechtig (2012), Impact of vegetation and soil moisture seasonal dynamics on dust emissions over the Sahel, J. Geophys. Res., 117, D06114, doi:10.1029/2011JD016950.

\section{Introduction}

[2] Atmospheric aerosols play an important role in the terrestrial environment. Mineral dust emitted from arid and semi-arid regions of the Earth represent about $40 \%$ of the annual tropospheric aerosol emissions [Intergovernmental Panel on Climate Change (IPCC), 2007]. This mineral aerosol has a significant radiative impact by scattering and/ or absorbing solar and telluric radiations all along its longrange transport from the source regions to the deposition areas [Sokolik and Toon, 1999; IPCC, 2007]. Mineral dust has also a biogeochemical impact on nutrients or micronutrients limited ecosystems: dust deposition represents an essential source of key elements (e.g. Fe, P, N) for large remote oceanic regions or semi-closed marine basins like the Mediterranean Sea [see, e.g., Jickells et al., 2005; Mahowald et al., 2008].

[3] Mineral dust is mainly produced by aeolian erosion from bare and unprotected surfaces in arid and semi arid areas. Numerous studies show that most of the global dust

\footnotetext{
${ }^{1}$ Geosciences Environnement Toulouse, Toulouse, France.

${ }^{2}$ Laboratoire Interuniversitaire des Systèmes Atmosphériques, Créteil, France.

${ }^{3}$ Biogéochimie et Écologie des Milieux Continentaux, Bondy, France.
}

Copyright 2012 by the American Geophysical Union. 0148-0227/12/2011JD016950 load is emitted from the main continental deserts like the Sahara and the Chinese desert [e.g. Ginoux et al., 2001; Tanaka and Chiba, 2006; Wang et al., 2011]. A wellmarked seasonal cycle of dust concentration is generally observed in connection with the seasonality of the windy periods [Moulin et al., 1998; Marticorena et al., 2010]. Over longer time scales, changes in the atmospheric dust load are linked to regional climatic changes. For example, the increase of the occurrence of dust haze (visibility lower than $<5 \mathrm{~km}$ ) in numerous Sahelian meteorological stations during the recent "Sahelian dry period" (late 60s - mid 90s) is generally attributed to a decrease of the vegetation cover [Mbourou et al., 1994, 1997]. Therefore, one can expect that the combined effects of climatic changes and of the increasing anthropogenic pressure in semi-arid areas lead to significant changes in the dust emitted from these regions.

[4] In semi-arid areas, seasonal precipitation affects dust emissions. In most cases (if sediment-supply is not limiting), precipitation and dust load are anticorrelated, as observed by Zender and Kwon [2005]. In the Sahel, the increase of soil moisture due to precipitation induces a reinforcement of the interparticle cohesion forces and thus increases the wind erosion threshold (i.e. the minimum wind velocity at which aeolian erosion starts) [Fécan et al., 1999]. The increase of soil moisture triggers the germination of annual and perennial plants. By covering partly the surface, the vegetation canopy limits and prevents loose soils from wind erosion. 
Sahelian precipitation occurs during a short rainy season, yielding to the development of herbaceous vegetation composed of grasses and forbs. During this period, surface properties like vegetation cover and surface roughness show a well marked dynamics [e.g., Tidjani, 2008]. The Sahel exhibits a sharp latitudinal precipitation and vegetation gradient between the arid Saharan zone to the North and the wet Sudanian zone to the South. Accordingly, the Sahelian surface properties display strong temporal and spatial variability that need to be carefully characterized to estimate dust emissions.

[5] Semi-arid regions, especially the Sahelian belt, are submitted to a strong anthropogenic pressure through cultivation and pasture, which also modify surface properties. It is usually assumed that these activities should yield to an increase in the aeolian erosion, particularly during the dry season and before sowing over cultivated bare fields [e.g., Rajot, 2001]. However, it remains very difficult to discriminate the proportion of dust resulting from natural or anthropogenic sources.

[6] In 1995, Tegen and Fung [1995] estimated that as much as 30 to $50 \%$ of the total atmospheric dust load are due to climatic changes and human activities. These authors considered that disturbed soils are more sensitive to erosion because they contain more loose particles that can be easily mobilized by wind. They constrained the sources contribution by comparing the simulated emissions to observed optical thicknesses. They assumed that the dependency on surface wind speed and soil moisture is the same for all deserts and sparsely vegetated areas. By using dust storm frequency, Tegen et al. [2004] estimated that dust emitted from "land use source" contribute up to $10 \%$ to the global dust load. However, Mahowald et al. [2004], using the same data but with a different model and methodology, show that a dust contribution of land use source ranging between 0 and $50 \%$ leads to similar agreement with observations. Another attempt of constraining dust emission from soil disturbance by comparing simulations and observations has been performed by Yoshioka et al. [2005] using the Absorbing Aerosol Indices (AAIs) derived from Total Ozone Mapping Spectrometer (TOMS) measurements. These authors get the best agreement between simulations and observations for a contribution of new desert and cultivation sources of 0 to $25 \%$ depending on the comparison criteria.

[7] From this literature, it appears as a key issue to estimate the "natural" Sahelian contribution to atmospheric dust load before integrating the impacts of human activities on aeolian erosion of the region. Therefore, the objective of the present work is twofold: (1) to provide a first estimate of the dust emissions from the "undisturbed" Sahel by combining a specific Sahelian vegetation model (Sahelian Transpiration, Evaporation and Productivity, STEP [Mougin et al., 1995; Tracol et al., 2006]) and a dust production model (MB) [Marticorena and Bergametti, 1995; Marticorena et al., 1997a; Laurent et al., 2008] and (2) to provide an evaluation of the effects of the seasonal dynamics of vegetation and surface soil moisture content on aeolian dust emission over Sahel. The models have been selected because they are based on explicit descriptions of the physical and biological processes associated to vegetation, soil moisture and surface roughness seasonal dynamics, and their combination constitutes an original and deterministic tool for estimating the semi-arid dust emissions. This strategy allows the surface characteristics to be estimated at temporal and spatial resolutions which are relevant regarding the variability of the precipitation and wind speed fields. A specific attention has also been paid to the input data, especially precipitation, which yield to vegetation development. The impact of surface soil moisture on dust emission having already been parameterized and tested [Fécan et al., 1999; Laurent et al., 2006, 2008], the critical issue remains the characterization of vegetation and surface roughness seasonal dynamics.

[8] Section 2 explains the physical basis of the dust emission modeling by presenting the two selected models, and introduces how the dynamic surface properties are estimated from the simulated vegetation. Section 3 presents the results of dust emission simulations with a discussion on the impacts of soil moisture and seasonal vegetation on dust emission. A concluding discussion is given in section 4 .

\section{Dust Emission Modeling}

[9] We used the dust emission model developed by Marticorena and Bergametti [1995], Marticorena et al. [1997a] and Laurent et al. [2008] - written MB hereafter. This model allows to account for the surface properties (soil moisture, roughness length, soil size distribution...) and the simulations of dust emissions performed by using this model have been extensively compared with observations [Marticorena et al., 1997a; Laurent et al., 2005; Laurent et al., 2008; Darmenova et al., 2009; Schmechtig et al., 2011].

[10] This subsection briefly describes the physical processes involved in dust emissions and their parameterization in the MB model. More details are provided by Marticorena and Bergametti [1995], Marticorena et al. [1997a, 1997b] and Fécan et al. [1999].

\subsection{The Dust Emission Model}

\subsubsection{General Principles}

[11] The amount of emitted soil particles by aeolian erosion is expressed as a power function of the wind friction velocity $U^{*}$, which is proportional to the wind shear stress on the surface. However, dust is only emitted if $U^{*}$ is greater than the so-called threshold wind friction velocity $U_{t}^{*}[$ e.g., Bagnold, 1941; Chepil, 1951]. This threshold value depends mainly on (1) the dry soil-grain size distribution, (2) the aeolian surface roughness, due to the presence of non erodible elements on the surface, and (3) the soil moisture.

[12] When the erosion threshold is reached, the soil grains follow a horizontal movement, through ballistic trajectories, called saltation. These particles constitute the horizontal flux $G$. If the provided energy when they strike the surface is sufficient (i.e., if it exceeds the interparticle cohesion forces of the aggregate), the soil aggregates can be disrupted: this phenomenon is called sandblasting. Hence, fine particles $(<20 \mu \mathrm{m})$ are emitted and constitute the vertical dust flux $F$ which contains the smallest dust particles that can be transported over long distances. The amount of matter in the vertical flux $F$ depends mainly on the availability of fine particles in the soil.

[13] To summarize, the key values parameterized in the MB model are the threshold wind friction velocity $U_{t}^{*}$, the horizontal flux $G$ and the vertical dust flux $F$. 


\subsubsection{Threshold Wind Friction Velocity}

[14] For an "aerodynamically smooth surface" (i.e. without obstacles), the threshold wind friction velocity depends mainly on the soil grain size. More precisely, for small grains (e.g. diameter $D_{p}<70 \mu \mathrm{m}$ ), interparticle cohesion forces (which increase when the grain size decreases) are predominant, whereas for coarse grains (e.g., $D_{p}>100 \mu \mathrm{m}$ ), their weight is. Therefore, grains having a size ranging between 70 and $100 \mu \mathrm{m}$ are the easiest to move [Bagnold, 1941]. A smooth surface roughness length $z_{0 s}$ is defined for the erodible surface, and the MB parameterization for the threshold wind friction velocity for the "smooth" surface $U_{t}^{*}\left(D_{p}, z_{0 s}\right)$ is derived from the semi-empirical expression proposed by Iversen and White [1982].

[15] Actually, the soil surface is rarely "smooth", because non erodible elements like vegetation, gravels and pebbles perturb the air flow. A part of the energy brought by the wind spreads on the roughness elements. This leads to a global decrease of the wind shear stress acting on the erodible surface and to an apparent increase of $U_{t}^{*}$ [Marticorena and Bergametti, 1995].

[16] To account for the effect on non erodible roughness elements, an efficient friction velocity ratio $f_{\text {eff }}$ is defined as the ratio of local to total friction velocity, i.e., the wind friction velocity on the erodible surface between roughness elements divided by the wind friction velocity over the whole surface. Moreover, in the MB model, the quantification of the non erodible roughness elements is based on the aerodynamic roughness length $Z_{0}$ which is considered as the direct indicator of the effect of the non erodible elements on the wind speed. Thus, the MB model predicts the threshold wind friction velocity from the aerodynamic roughness length of the surface. This approach has been validated over a large surface roughness range, from smooth erodible surfaces to rough surfaces almost totally protected from wind erosion, using numerous field measurements performed on various sites [Marticorena et al., 1997b].

[17] The soil moisture of the top soil layer, called hereafter surface soil moisture $w$, has also an impact ( $f_{w}$ hereafter) on the threshold wind velocity. Water films due to molecular adsorption appear on the grain surface and water wedges due to capillary forces are formed around the contact points of the soil grains [Fécan et al., 1999]. The amount of adsorbed water increases progressively with the total soil moisture until it reaches a limit, corresponding to the maximum amount of water that the adsorption molecular forces can trap, and called hereafter the residual soil moisture $w_{0}$. According to Fécan et al. [1999], when $w$ is smaller than $w_{0}$, the capillary moisture does not induce strong coherence forces, i.e., $w_{0}$ corresponds to the minimum soil moisture from which the threshold wind friction velocity increases. The impact of soil moisture on the wind erosion threshold is given by the empirical relationship proposed by Fécan et al. [1999]:

$$
f_{w}= \begin{cases}1 & \text { if } w<w_{0} \\ {\left[1+1.21\left(w-w_{0}\right)^{0.68}\right]^{0.5}} & \text { if } w>w_{0}\end{cases}
$$

where $w_{0}$ is the residual volumetric soil moisture (in $\mathrm{m}^{3}$. $\mathrm{m}^{-3}$ ) which depends on the soil texture. This last value is determined from the soil clay content $\%_{\text {clay }}$ as follows: $w_{0}=$ $0.0014\left(\%_{\text {clay }}\right)^{2}+0.17\left(\%_{\text {clay }}\right)$.
[18] Finally, the threshold wind friction velocity, $U_{t}^{*}\left(\right.$ in $\left.\mathrm{cm} \cdot \mathrm{s}^{-1}\right)$, is expressed as:

$$
U_{t}^{*}\left(D_{p}, Z_{0}, z_{0 s}, w\right)=f_{w} \cdot U_{t}^{*}\left(D_{p}, z_{0 s}\right) / f_{\text {eff }}\left(Z_{0}, z_{0 s}\right)
$$

where

$D_{p}$ is the particle diameter (in $\mathrm{cm}$ ),

$Z_{0}$ is the total surface roughness length (in $\mathrm{cm}$ ),

$z_{0 s}$ is the smooth surface roughness length (in $\mathrm{cm}$ ),

$w$ is the volumetric soil moisture (in $\mathrm{m}^{3} \cdot \mathrm{m}^{-3}$ ).

\subsubsection{Dust Emission Fluxes}

[19] Once a soil grain is in motion, its trajectory depends on the forces that exert on it. Here the weight is considered as the overwhelming force the soil grain is submitted to. Therefore the soil grain trajectory depends on its weight or, as a first approximation, on the grain size. The largest grains $\left(D_{p}>1000 \mu \mathrm{m}\right)$ cannot leave the surface and creep on the soil. The intermediate-sized grains $\left(D_{p}=70\right.$ to $\left.1000 \mu \mathrm{m}\right)$ have a saltating movement and constitute the horizontally integrated flux $G$, expressed in $\mathrm{kg} \mathrm{m}^{-1} \mathrm{~s}^{-1}$.

[20] In the MB model, according to White [1979], the horizontal flux $G$ proportional to the third power of the wind friction velocity $\mathrm{U}^{*}$ when $\mathrm{U}^{*}$ is greater than the threshold wind friction velocity. Moreover, $G$ is only computed on the part of the surface not covered by roughness elements, i.e. the fraction of erodible surface $E$.

[21] To determine the contribution of the different soil grain sizes to the horizontal flux $G$, Marticorena and Bergametti [1995] assume that their contribution depends on (1) the threshold wind friction velocity of each grain size and (2) the relative surface that this grain size occupies on the surface. Finally, the following parameterization is proposed for $G$ :

$$
\begin{aligned}
G= & E\left(\rho_{a} / g\right) U^{* 3} \Sigma_{D p}\left[1+U_{t}^{*}\left(D_{p}, Z_{0}, z_{0 s}\right) / U^{*}\right] \\
& \cdot\left[1-U_{t}^{*}\left(D_{p}, Z_{0}, z_{0 s}\right)^{2} / U^{* 2}\right] d S_{r e l}\left(D_{p}\right) d D_{p}
\end{aligned}
$$

where

$E$ is the fraction of erodible surface to total surface, $\rho_{a}$ is the air density (equal to $1.227 \mathrm{~kg} \mathrm{~m}^{-3}$ ),

$Z_{0}$ is the total surface roughness length (in $\mathrm{cm}$ ),

$z_{0 s}$ is the smooth surface roughness length (in $\mathrm{cm}$ ),

$d S_{r e l}\left(D_{p}\right)$ is the relative surface covered by the particles of diameter $D_{p}$.

[22] The simulated size distribution of the saltating grains has been validated by comparisons to wind tunnel measurements [Marticorena and Bergametti, 1995].

[23] According to Marticorena and Bergametti [1995], the link between horizontal and vertical flux is considered to depend mainly on the content in aggregates composed of fine particles of the erodible soil. Based on Gillette's [1974] measurements, Marticorena and Bergametti [1995] assumed that the content of fine particles can be estimated from the soil clay content and proposed an empirical relationship linking the ratio of the vertical to horizontal flux to the percentage of clay of the soil.:

$$
F / G=10^{[0.134(\% \text { clay })-6]}
$$


[24] However, as precisely shown by Marticorena and Bergametti [1995], (equation 4) is not relevant for soils having a clay content greater than $20 \%$. Indeed, soils with high clay content might be crusted, and thus resistant to wind erosion [Chepil, 1951]. Soils containing more than $20 \%$ clay are therefore considered here as non erodible.

[25] Recent studies proposed physical explicit representations of the sandblasting phenomenon [Lu and Shao, 1999; Alfaro and Gomes, 2001; Kok, 2011]. Yet these models, dedicated to the simulation of the dust size distribution, require specific parameters that are difficult to constrain at regional scale. Since the present study aims at quantifying the mass of dust emitted from the Sahel, the empirical relation defined by Marticorena and Bergametti [1995] and updated by Laurent et al. [2008] has been kept here.

\subsubsection{Input Data}

[26] The data required when applying the MB model at a regional scale are: the wind velocity, the surface roughness length for the "smooth" erodible surface $\left(z_{0 s}\right)$, the surface roughness length taking into account the obstacles $\left(Z_{0}\right)$, the fraction of erodible surface $(E)$, the dry soil grain size distribution, the soil clay content, and the surface soil moisture.

[27] In the Sahel, during the rainy season, the characteristics of the herbaceous canopy vary significantly from day to day [see, e.g., Pierre et al., 2011], especially during the growing period. Thus they need to be described with a daily timescale. After presenting the wind velocity data sets, the determination of the surface properties that remain constant over time (hereafter called "static surface properties") will be addressed below, before handling the issue of the dynamic surface properties in chapter 2.2.

\subsubsection{Wind Velocity Data}

[28] The wind energy transmitted to the surface is linked to the friction velocity on the surface, which can be expressed as a function of the wind velocity at a reference height through a logarithmic profile [Priestley, 1959]. Such wind velocities are provided by the European Centre for Medium range Weather Forecast (ECMWF) or the National Center for Environmental Prediction (NCEP). Recent studies suggest that over Africa the ECMWF analyzed wind fields could be more reliable than the NCEP ones. Indeed, Colarco et al. [2002] and Menut [2008] have shown how strongly these two databases differ, and Koren and Kaufman [2004] concluded that the NCEP wind velocities over North Africa are significantly lower than those retrieved by the analysis of a dust plume movement observed by satellite.

[29] For this reason, we selected the ECMWF analyzed wind fields. These values are computed with a temporal resolution of 3 hours, and at a spatial resolution of $0.28125^{\circ}$ from January 2004 to January 2006 , and of $0.225^{\circ}$ since February 2006. They are interpolated and provided at $0.25^{\circ}$ spatial resolution. As proposed by Marticorena et al. [1997a], once the surface roughness length $Z_{0}$ is determined, the wind friction velocity $U^{*}$ is computed from the wind velocity at 10 meters height, assuming the logarithmic wind profile described by Priestley [1959]. The use of this last parameterization implies the assumption of atmospheric neutrality from the surface to 10 meters of altitude. It means that the friction velocity during dust emission events is considered as mostly dependent on the dynamics effect rather than on the stability effects. This hypothesis that the correction accounting for non-neutrality can be neglected during dust emission events has been confirmed by Darmenova et al. [2009].

\subsubsection{Static Surface Properties}

[30] The soil size distribution is required to estimate the respective contribution to the horizontal flux $G$ of the different grain size classes. Based on numerous Saharian and Sahelian soil samples, Chatenet et al. [1996] showed that the soil size distribution of an erodible soil can be represented by a combination in different proportions of four main soil components: alumino-silicated silts, fine sand, coarse sand and salts. Each of these components is represented by a lognormal distribution characterized by its mass median diameter and its standard deviation. Marticorena et al. [1997a] and Callot et al. [2000] produced a map of the Saharan surface properties at a $1^{\circ} \times$ $1^{\circ}$ spatial resolution, by defining 12 soil types for the Sahara and Sahel regions. These soil types were described by (1) the relative contribution of each of the 4 different components mentioned above to their soil size distribution and (2) their soil clay content. In each grid cell, up to 5 soil types can be represented. An improvement has been brought to this map by increasing its spatial resolution to $0.25^{\circ} \times 0.25^{\circ}$ from $38^{\circ} \mathrm{N}$ to $16^{\circ} \mathrm{N}$ [Laurent et al., 2008]. The same methodology as used by Callot et al. [2000] has been used here to extend this map over our area of interest (i.e., down to $12^{\circ} \mathrm{N}$ ).

[31] According to the drag partition proposed by the authors (see section 2.1.2), two roughness lengths are required to describe a surface without seasonal vegetation: (1) the "smooth" roughness length of the bare soil $z_{0 s}$ and (2) the "static" surface roughness length, taking into account the presence of gravels, pebbles and perennial vegetation on the surface.

[32] The "smooth" roughness length, $z_{0 s}$ in $\mathrm{cm}$, can be estimated from the soil grain size as follows [Greeley and Iversen, 1985]:

$$
z_{0 s}=D_{p} / 30
$$

where $D_{p}$ is the mass median diameter of the coarser soil population (in $\mathrm{cm}$ ) for each soil type mapped in the considered grid cell, as in work by Marticorena et al. [1997a] and Laurent et al. [2008].

[33] The "static" surface roughness is estimated from the Bidirectional Reflectance Distribution Functions (BRDF) deduced from the ADEOS (Advanced Earth Observing Satellite) POLDER-1 (POLarization and Directionality of the Earth's Reflectances) measurements. The methodology is described by Marticorena et al. [2004] and allows retrieving with a good confidence aeolian roughness lengths at the $1 / 16^{\circ}$ spatial resolution. Briefly, an empirical relationship has been established between a so-called protrusion coefficient (derived from the BRDF [see Roujean et al., 1992]) and the surface roughness derived from a geomorphologic approach [Marticorena et al., 1997a; Callot et al., 2000]. A composite map is obtained using the BRDF for months which are not affected by heavy mineral dust load. As shown by Marticorena et al. [2004], the aggregation of the initial data (which are at a spatial resolution of $1 / 16^{\circ}$ ) up to $0.25^{\circ}$ does not affect significantly the retrieval of the roughness length. Thus, we used the $0.25^{\circ}$ data as did Laurent et al. [2008] to simulate dust emissions over the Sahara desert. When POLDER-1 data is missing over the study area (due to the presence of clouds or to the data 


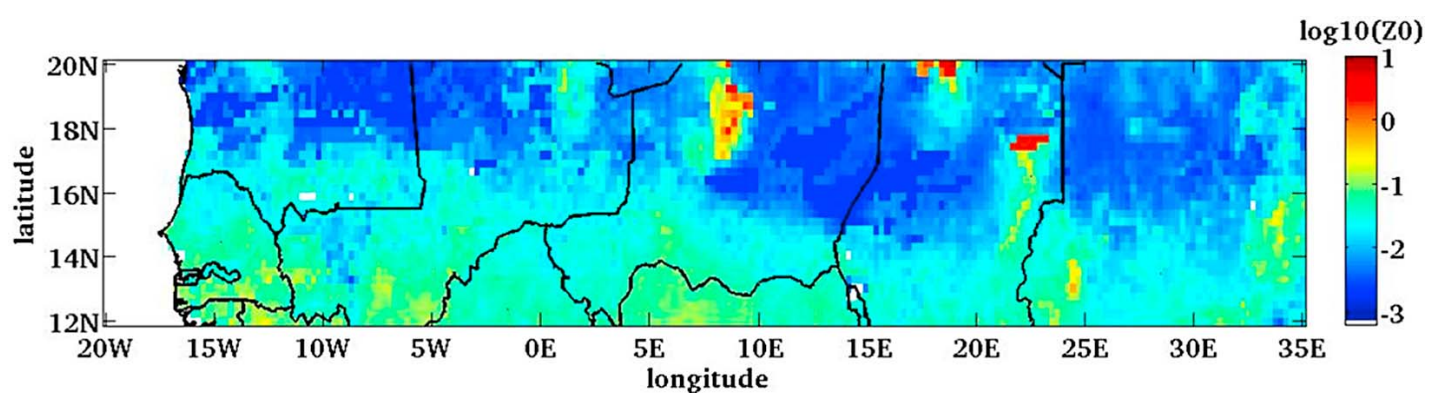

Figure 1. Aerodynamic surface roughness length $Z_{0}$ (in $\mathrm{cm}$ expressed in logarithm) derived from POLDER-1 measurements (spatial resolution: $0.25^{\circ}$ ).

selection; this represent about $20 \%$ of the initial dataset), the corresponding surface roughness length is estimated from the longitudinally surrounding values. Finally, if the static roughness length is smaller than the smooth roughness length $z_{0 s}$, they are considered as both equal to the latter. This whole approach has also been applied for modeling dust emissions in other areas, such as Chinese deserts [Laurent et al., 2005, 2006] and central Asia [Darmenova et al., 2009].

[34] Additionally, the perennial vegetation can affect the surface roughness. Yet the present study is focused on a part of Sahel were herbaceous vegetation is the main vegetation, bushes and trees being rare on the considered area and at the considered scale [Le Houerou, 1989]. Thus the roughness effects due to the perennial vegetation are considered as accounted for by the surface roughness determined from POLDER satellite-measurements during the dry season.

[35] The obtained roughness map (Figure 1) shows a strong latitudinal gradient, with increasing values when going from north to south. This indicates that more roughness elements are present in the south of the area, probably because of the presence of perennial herbaceous and woody vegetation. Conversely, the surface roughness is the lowest at the northern edge (between $18^{\circ} \mathrm{N}$ and $20^{\circ} \mathrm{N}$ ) of the zone, where there are large sand dune structures (so-called ergs). Mountains and high relieves $\left(10^{\circ} \mathrm{E}, 17^{\circ} \mathrm{N}\right.$ to $20^{\circ} \mathrm{N}$ : the Aïr Azbine massif in Niger; $20^{\circ} \mathrm{E}, 20^{\circ} \mathrm{N}$ and $22^{\circ} \mathrm{E}, 17^{\circ} \mathrm{N}$ : respectively the Tibesti and Ennedi massifs in Tchad) exhibit very high values of surface roughness $\left(Z_{0}\right.$ is about $\left.5 \mathrm{~cm}\right)$.

[36] Finally, the erodible surface fraction $E$, which is the proportion of the surface not covered by roughness elements, is required to compute the horizontal flux $G$. Indeed, roughness elements are assumed to cover part of the surface and to prevent it from erosion. According to the empirical relationship established by Laurent et al. [2008] over the Sahara, we assumed that the fraction of the erodible surface $E$ decreases roughly as a function of the roughness length, the surface being considered as totally erodible when $Z_{0}$ is smaller than $3.10^{-3} \mathrm{~cm}$ :

$$
E=\left\{\begin{array}{ll}
1 & \text { if } Z_{0}<3.10^{-3} \mathrm{~cm} \\
0.7304-\left(0.0804 \log _{10}\left(Z_{0}\right)\right) & \text { if } Z_{0}>3.10^{-3} \mathrm{~cm}
\end{array} .\right.
$$

\subsection{The Vegetation Model}

[37] To perform dust emission simulations over the Sahel, dynamic surface properties - namely the roughness induced by annual herbaceous vegetation and the shallow soil moisture have to be estimated. These variables are provided by the STEP model [Mougin et al., 1995; Tracol et al., 2006].

\subsubsection{General Principles}

[38] The STEP model has been designed to simulate, at a daily time scale, the growth of the annual herbaceous canopy by describing explicitly the physical and biological processes associated to plant growth (photosynthesis, respiration, senescence and litter production) and water budget (evaporation, transpiration, water fluxes in the soil) in a Sahelian environment. The modeled vegetation consists of an herbaceous layer composed of annual species. From the simulated biomass, vegetation structural parameters such as Leaf Area Index (LAI), Vegetation Cover Fraction $\left(f_{v}\right)$, vegetation height $(h)$ and soil moisture $(w)$ are estimated, allowing comparisons with satellite or field measurements [e.g., Lo Seen et al., 1995; Tracol et al., 2006]. While the STEP model was initially designed for 1D-simulations in well documented study sites, it has also been recently used by Pierre et al. [2011] for regional applications.

\subsubsection{Sahelian Vegetation Modeling \\ 2.2.2.1. Water Budget}

[39] Daily rainfall is used as an input in the STEP model. At the considered resolution $\left(0.25^{\circ}\right)$, only a simple water budget model can be used. Only the following processes are retained: water infiltration into the soil profile, soil evaporation and plant transpiration. Run-off is neglected. This is a realistic assumption since the herbaceous layer mostly develops on the endorheic sandy dune systems for which the redistribution of water operates at short distance within small adjacent catchments [Mougin et al., 2009a]. The soil is divided into 2 main layers of respectively $30 \mathrm{~cm}$ and $1 \mathrm{~m}$ depth, and a surface layer of $2 \mathrm{~cm}$ depth which is required for modeling aeolian erosion processes.

[40] The water budget is based on the tipping bucket scheme: water penetrates a layer until it fills this layer up to its field capacity (the maximum amount of water the layer can contain), and then flows to the following layer. For each layer, the variation of the water content is the result of its drainage, its contribution to evapotranspiration, and the water income, constituted by rainfall or drainage from the upper layer.

\subsubsection{Growth Model}

[41] Biomass is divided into four components: green biomass, roots biomass, standing dead biomass and litter biomass. Vegetation growth starts at seedling emergence with an initial green biomass called $B_{g 0}$. Then each component is filled by another one: green biomass becomes standing dead biomass, which becomes litter biomass. Green biomass 
variations are driven by water income (i.e., rainfall) and radiation, allowing germination and then photosynthesis. The latter is limited by respiration, temperature and water availability, and can be expressed as follows:

$$
\mathrm{P}=\mathrm{PAR} * \varepsilon_{\mathrm{i}} * \varepsilon_{\mathrm{c}} * \mathrm{f}\left(w_{a}\right) * \mathrm{f}(\mathrm{T})
$$

where:

$\mathrm{P}$ is the matter produced by photosynthesis (in $\mathrm{g} \mathrm{m}^{-2}$ ),

PAR is the Phosynthetically Active Radiation (in $\mathrm{W} \mathrm{m}^{-2}$ ),

$\varepsilon_{\mathrm{i}}$ is the interception efficiency (proportion of the PAR intercepted by plants, estimated from the LAI),

$\varepsilon_{\mathrm{c}}$ is the conversion efficiency (in $\mathrm{g} \mathrm{MJ}^{-1}$ ), i.e. the amount of matter that can produce the plant with a given amount of energy,

$w_{a}$ is the water availability $\left(\right.$ in $\mathrm{m}^{3} \mathrm{~m}^{-3}$ ), and $\mathrm{T}$ is the temperature $\left(\right.$ in $\left.{ }^{\circ} \mathrm{C}\right)$.

[42] It should be noticed that the impact of the biomass burning can be neglected since it has been shown that it mostly affects the Sudanian area and only marginally the southern edge of the Sahel [Roberts et al., 2008; Stroppiana et al., 2010].

\subsubsection{Input Data}

[43] The main required input data sets are daily meteorological data (air temperature, global radiation, rainfall) and soil characteristics (texture with depth, albedo), input parameters being the initial green biomass $\left(\mathrm{B}_{\mathrm{g} 0}\right)$, and the maximum conversion efficiency $\left(\varepsilon_{\mathrm{c}}\right)$. A thorough description of these parameters are provided by Mougin et al. [1995]. Here, they are estimated using the Moderate Resolution Imaging Spectroradiometer (MODIS) (LAI) data set [Myneni et al., 2002] as indicated by Pierre et al. [2011]. This database has been selected for its fine resolution $(\sim 1 \mathrm{~km}, 8$ days $)$ and its good skills over Sahel [Fensholt et al., 2004; Mougin et al., 2009b].

[44] The selection of the rainfall used as input data is based on an intercomparison of satellite-based rainfall products and interpolated field gauge measurements over the Sahel according to relevant criteria for vegetation modeling [Pierre et al., 2011]. Following this study, the satellitederived product $3 \mathrm{~B} 42\left(0.25^{\circ}\right)$ [Huffman et al., 2007] from the Tropical Rainfall Measuring Mission (TRMM) has been selected for its good skills over the area of interest. The other meteorological parameters are operational data from the ECMWF. Soil textures profiles are adapted from the Harmonized World Soil Database (HWSD) (FAO/IIASA/ ISRIC/ISS-CAS/JRC, Harmonized World Soil Database (version 1.1), 2009, http://www.globalsoilmap.net/content/ harmonized-world-soil-database-version-11), which is the current finest available soil database. Its resolution is about 1 $\mathrm{km}$; data are aggregated at the $0.25^{\circ}$ resolution. Surface albedo is the product provided by the MODIS database. Finally, the model is reinitialized every year in order to prevent possible drifting.

\subsubsection{Model Outputs}

[45] The main model outputs are vegetation biomass and LAI. Vegetation height $h$ is estimated from the simulated biomass and cannot exceed $40 \mathrm{~cm}$ (observed maximum height of the mean herbaceous layer according to direct field measurements [Mougin et al., 1995]). The vegetation cover $\mathrm{f}_{\mathrm{v}}$ is deduced from the simulated LAI through an empirical relationship (E. Mougin et al., Estimation of LAI, fCover and fAPAR of a Sahelian grassland (Gourma, Mali), submitted to Agricultural and Forest Meteorology, 2012), and can vary between 0 and 1 .

[46] The vegetation simulated by the STEP model over the whole area (Figure 2) shows a realistic pattern in accordance with previous studies [Justice et al., 1985; Anyamba and Tucker, 2005]: sparse vegetation starts to develop around June 1st at the southern edge of the area, before constituting a continuous field around July 1st. During the following weeks, the northern edge of the vegetated field shifts towards the north and LAI increases until reaching a maximum around 1 September. At 1 October, the vegetation field becomes strongly discontinuous because of the senescence.

[47] The quality of the simulations was previously evaluated by examining the main features of the vegetation dynamics and their agreement with MODIS LAI [Pierre et al., 2011]: location of the northern limit of the vegetated area, dates of beginning of the plant growth (T0) and of biomass maximum, and LAI values at T0+15 days and at vegetation maximum. As a result of these comparisons, the simulated vegetation is spatially and temporally consistent at the regional scale with the satellite observations. The cumulated distributions of dates of beginning of vegetation growth and of vegetation maximum also show a good agreement with MODIS observations, the inflection points occurring respectively at Day Of Year (DOY) 150 (end of May) and DOY 250 (early September). Finally, simulated LAI values at $\mathrm{T} 0+15$ days and at vegetation maximum show significant agreement with MODIS LAI, the correlation coefficients being respectively 0.67 and 0.81 for the 4 -years period (2004 to 2007) [Pierre et al., 2011]. According to these criteria, the regional vegetation cycle is thus satisfyingly reproduced by the model.

\subsection{Dynamic Surface Properties Over the Sahel}

\subsubsection{Simulated Soil Moisture}

[48] As explained in the previous subsection, soil moisture in the STEP model depends on rainfall, soil texture, daily extrema temperatures, incoming radiation and wind velocity. An example of simulated surface soil moisture is given in Figure 3 in volumetric units $\left(\% \mathrm{~m}^{3} \mathrm{~m}^{-3}\right)$. As expected from the Sahelian rainfall characteristics, the simulated surface soil moisture reaches its highest values (up to 20\%) during the core of the rainy season (i.e. between middle of July and early September, see DOY 200 and 250). At the beginning (DOY 100) and the end (DOY 300) of the year, soil moisture values are much lower (maximum 2 to $10 \%$ ). During the rainy season, soil moisture exhibits the same strong latitudinal gradient as observed for rainfall (with the highest values to the south) [Pierre et al., 2011]. Some areas with higher soil moisture values are observed at $5^{\circ} \mathrm{W}, 12^{\circ} \mathrm{N}-$ $14^{\circ} \mathrm{N}$ and at the south-eastern corner of the area, corresponding respectively to the interior Delta of Niger and to a convergence zone of several Nile tributaries. The high clay content of the soils in these areas may explain such high moisture values.

\subsubsection{Estimated Surface Roughness}

[49] The estimation of the surface roughness induced by the seasonal dynamics of herbaceous vegetation is highly 


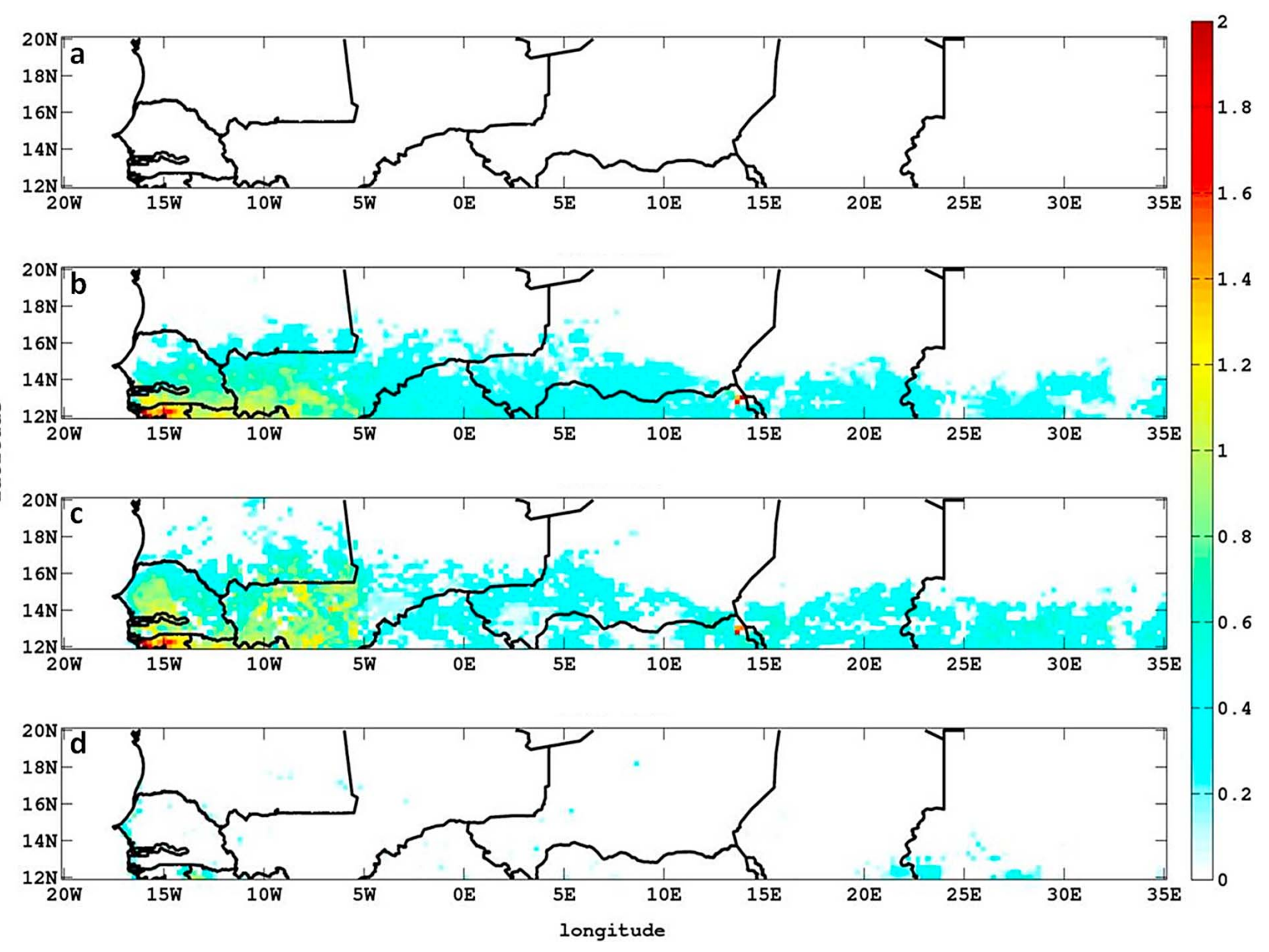

Figure 2. LAI (in $\mathrm{m}^{2} / \mathrm{m}^{2}$ ) simulated by the STEP model run with the TRMM3B42 product as rainfall forcing, at Days of Year (DOY) (a) 100, (b) 200, (c) 250 and (d) 300 for year 2004.

challenging. Surface roughness length in the case of bushes and pebbles can be estimated as a function of the geometrical properties of these obstacles and of their surface cover [Marticorena et al., 1997a]. Such a relation between geometrical properties and aerodynamic roughness length is not available for the herbaceous layer. Assuming that an herbaceous "patch" can be considered as similar to a bush, the induced aerodynamic surface roughness height can be estimated from the height and width of herbaceous patches. Sahelian herbaceous vegetation does not spread homogenously. Its spreading depends mainly on the microtopography. Yet, microtopography inside each grid cell cannot be documented over the whole area of interest with the required resolution. To account for this heterogeneity in surface cover, vegetation patches are represented by circles of 5 meters in diameter, whose number increases with the simulated vegetation cover rate.

[50] Based on this hypothesis, the roughness density $\lambda$, defined as the ratio of the lateral area of the obstacles over the ground surface [e.g., Marticorena and Bergametti, 1995], is expressed as follows:

$$
\lambda=4 \mathrm{f}_{\mathrm{v}} h /(5 \pi)
$$

with $h$ in $\mathrm{m}, \lambda$ non dimensional.
[51] An empirical relationship has been established, based on wind-tunnel measurements for compact obstacles, between the roughness density $\lambda$, the vegetation height $h$ and the surface roughness length $Z_{0}$ [Marticorena et al., 1997a]. Its extension to obstacles which porosity is low [up to $25 \%$, Minvielle et al., 2003] has been validated with field measurements [Marticorena et al., 2006]:

$$
Z_{0}= \begin{cases}h 10^{(1.31 \log (\lambda)-0.66)} & \text { if } \lambda<0.041 \text { and } h>0 \\ h 110^{(-1.16)} & \text { else. }\end{cases}
$$

for $\mathrm{Z}_{0}$ and $h$ in $\mathrm{cm}$.

Two comments can be done on (equation 9):

[52] 1. The strict accounting for grass porosity would require a precise description of the vegetation structure, as noticed by Bégué [1991]. Yet, the existing studies dealing with vegetation structure and roughness consider mainly the role of bushes [MacKinnon et al., 2004; King et al., 2005; Marticorena et al., 2006] and not that the grass plays. Thus the porosity of the herbaceous layer cannot be accounted for here due to the lack of information. It is assumed that (equation 9), which is valid for obstacles porosity up to $25 \%$, still applies for the herbaceous layer. 

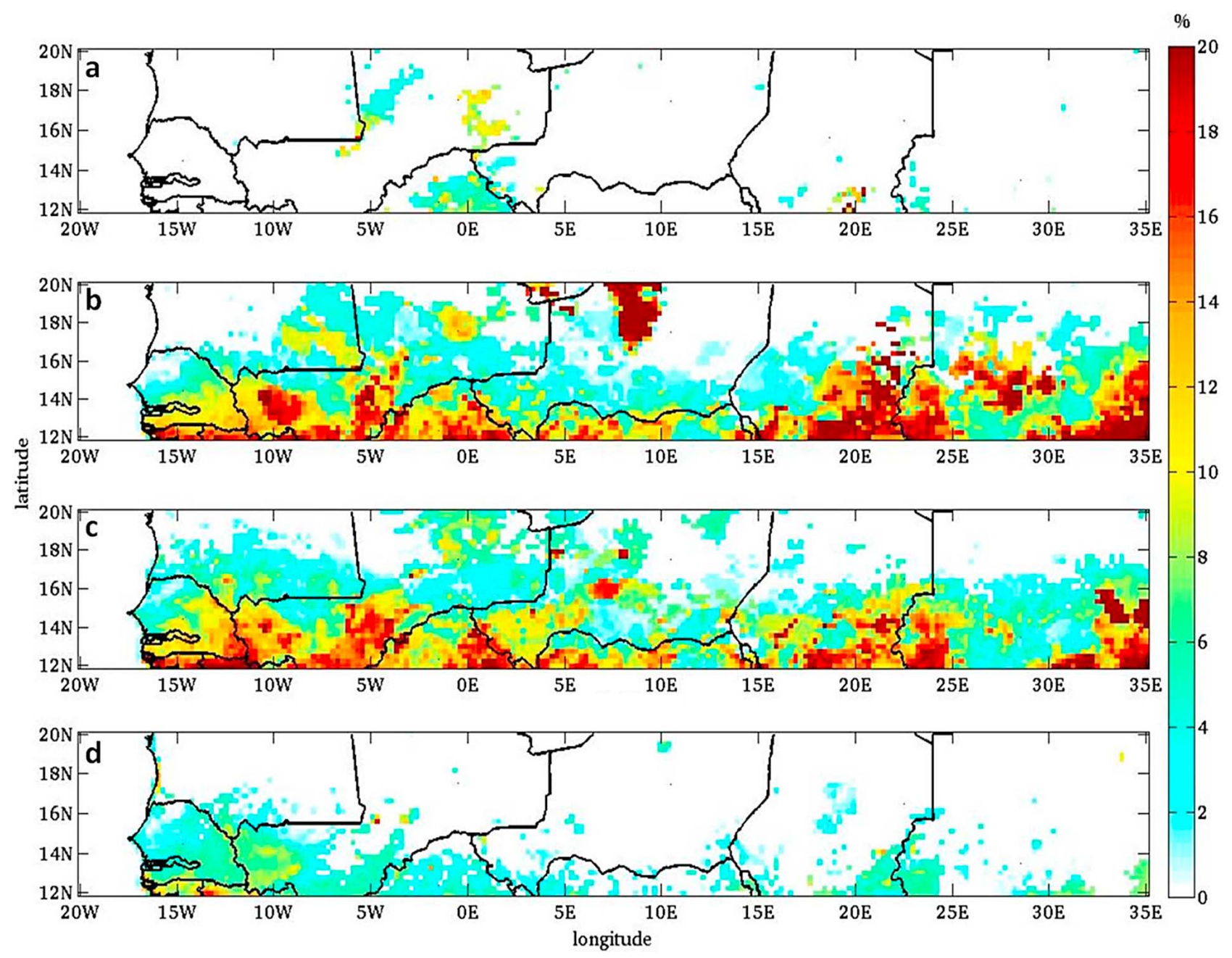

Figure 3. Volumetric superficial soil moisture (in $\% \mathrm{~m}^{3} \mathrm{~m}^{-3}$ ) simulated by the STEP model run with the TRMM3B42 product as rainfall forcing at DOY (a) 100, (b) 200, (c) 250 and (d) 300 for year 2004.

[53] 2. It is noticeable that the maximum limit of $40 \mathrm{~cm}$ for the vegetation height $h$ does not have a significant impact on aeolian erosion simulation: indeed, when such important vegetation cover and height are reached, the soil surface is protected from erosion (second case in (equation 9)).

[54] Moreover, if $\mathrm{f}_{\mathrm{v}}>0$, the fraction of erodible surface $E$ becomes $E^{\prime}$ :

$$
E^{\prime}=E\left(1-\mathrm{f}_{\mathrm{v}}\right)
$$

By default, static parameters are used for the dust emission computations, except for soil moisture. Once the vegetationinduced roughness length is higher than the static roughness length, dynamic surface parameters are used instead of the static parameters.

[55] The seasonal variation of the herbaceous vegetation has a strong impact on the surface roughness. Figure 4 shows the logarithm of aerodynamic roughness length in response to the seasonal variation of vegetation (in $\mathrm{cm}$ ) for year 2004. First of all, the representation of vegetation gives realistic values of aerodynamic surface roughness length $Z_{0}$, ranging between $10^{-5} \mathrm{~m}$ and $10^{-1} \mathrm{~m}\left(\log _{10}\left(Z_{0 \mathrm{~cm}}\right)\right.$ between -3 and +1$)$. These values are in agreement with the measurements of Tidjani [2008], who obtained a $\mathrm{Z}_{0}$ varying between $10^{-4} \mathrm{~m}$ and $5.10^{-2} \mathrm{~m}$ over a study site in the Damagaram (south eastern Niger). Abdourhamane Touré et al. [2011] also obtained similar values with measurements in Banizoumbou (south western Niger): $Z_{0}$ varying between $10^{-5} \mathrm{~m}$ and $10^{-4} \mathrm{~m}$ over bare surfaces and between $10^{-3} \mathrm{~m}$ and $10^{-1} \mathrm{~m}$ over cultivated ones.

[56] Figure 4 highlights the very strong dynamics of the surface roughness: in early April (DOY 100), the rainy season has not started yet and no seasonal vegetation is present. The roughness length is thus the "static" one (the one of the dry season). Once the rainy season has started, vegetation height and surface cover rate increase. As a consequence, the roughness length increases as illustrated for mid-July (DOY 200) and early September (DOY 250). At the end of October (DOY 300), the senescence stage yields to a decreasing roughness length in concordance with vegetation decay triggered by the lack of water in the rooting zone. These results are also in good agreement with the dynamics of measurements by Abdourhamane Touré et al. [2011] and Tidjani [2008], with a minimum $\mathrm{Z}_{0}$ in April, increasing values in July and August, until reaching a 

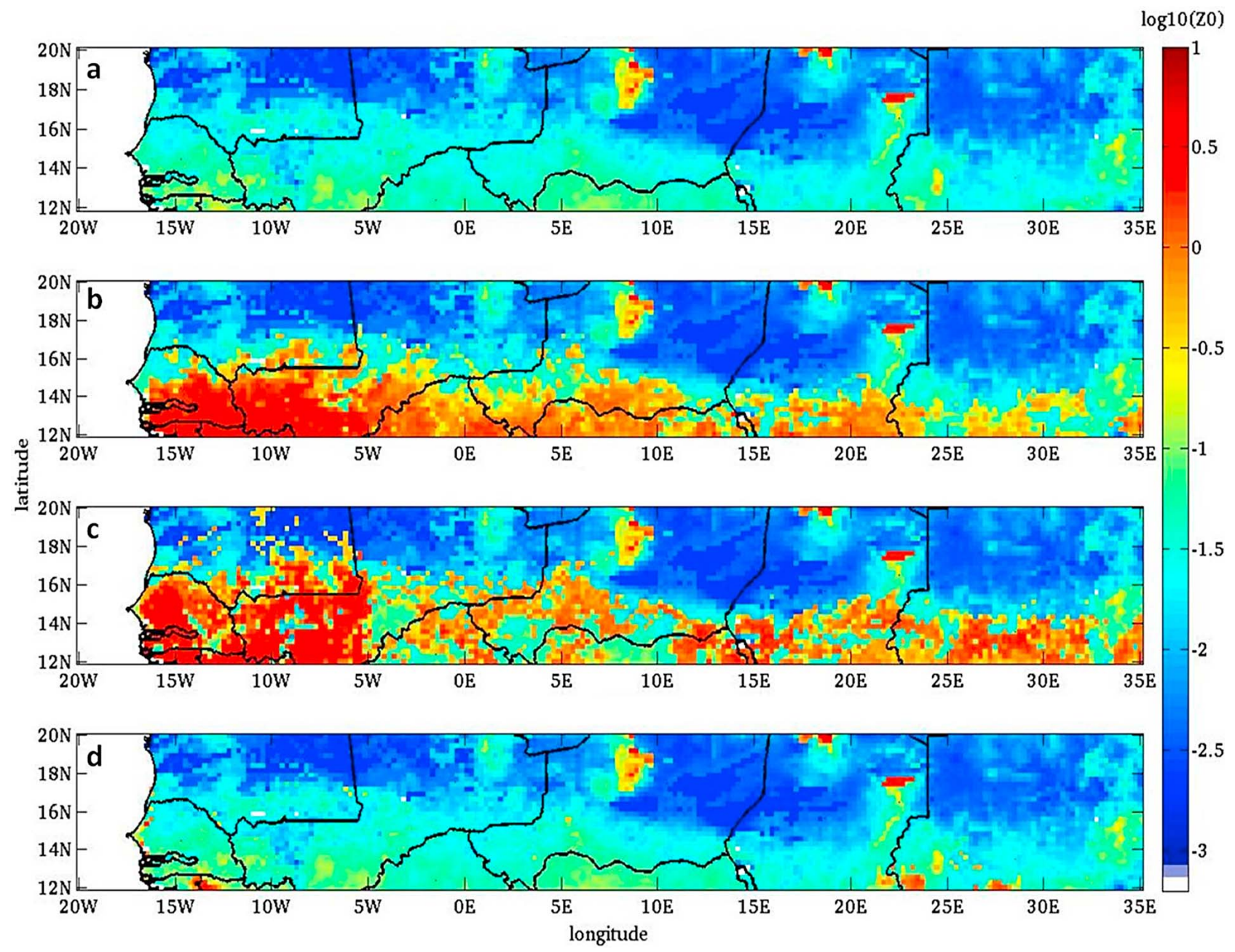

Figure 4. Aerodynamic surface roughness length $Z_{0}$ (in $\mathrm{cm}$ ) expressed in logarithm, taking into account the static surface roughness and the dynamics of vegetation simulated by the STEP model run with the TRMM3B42 as rainfall forcing at DOY (a) 100, (b) 200, (c) 250 and (d) 300 for year 2004.

maximum around September and October, and a decrease from November to the following dry season.

\section{Results}

\subsection{Impact of the Seasonal Dynamics of Soil Moisture and Vegetation on $U_{t}^{*}$}

\subsubsection{Dry Season}

[57] The impact of the herbaceous vegetation and surface soil moisture on the threshold wind friction velocity is illustrated in the following subsection. The minimum threshold wind friction velocity is observed for the dry season when no green herbaceous vegetation is present and when the surface soil moisture is minimum (Figure 5). Straws and litter from the previous rainy season might be present during part of the dry season, depending mainly on grazing intensity [Hiernaux et al., 2009]. The phenomena involved in their disappearance (fodder intake and trampling by cattle, degradation by termites and small mammals) are difficult to document at a regional scale with a pertinent sampling frequency.
[58] Additionally, since there is no satellite-based product for dry vegetation, the model outputs in terms of dry vegetation cannot be evaluated. Yet, the most frequent strong winds occur right before the rainy season and at its very beginning when straw and litter cover are minimum [Rajot, 2001; Marticorena et al., 2010]. Thus, most of dust emissions occur during this period. These reasons motivated the focus of the present study on the green vegetation and its inhibiting capabilities.

[59] The threshold wind friction velocities range between $20 \mathrm{~cm} \mathrm{~s}^{-1}$ and $80 \mathrm{~cm} \mathrm{~s}^{-1}$, except in the mountainous zones. A latitudinal gradient is observed with greater threshold wind friction velocities to the south compared to the north. As already noticed in Figure 1, this might be partly due to the presence of perennial vegetation in the southern part of the simulated area.

\subsubsection{Impact of the Surface Soil Moisture}

[60] The threshold wind friction velocity increases in the south of the area during the rainy season. As a consequence, the ratio of the threshold wind friction velocity with and without soil moisture evolves between 1 (i.e. no increase, 
$\mathrm{cm} / \mathrm{s}$

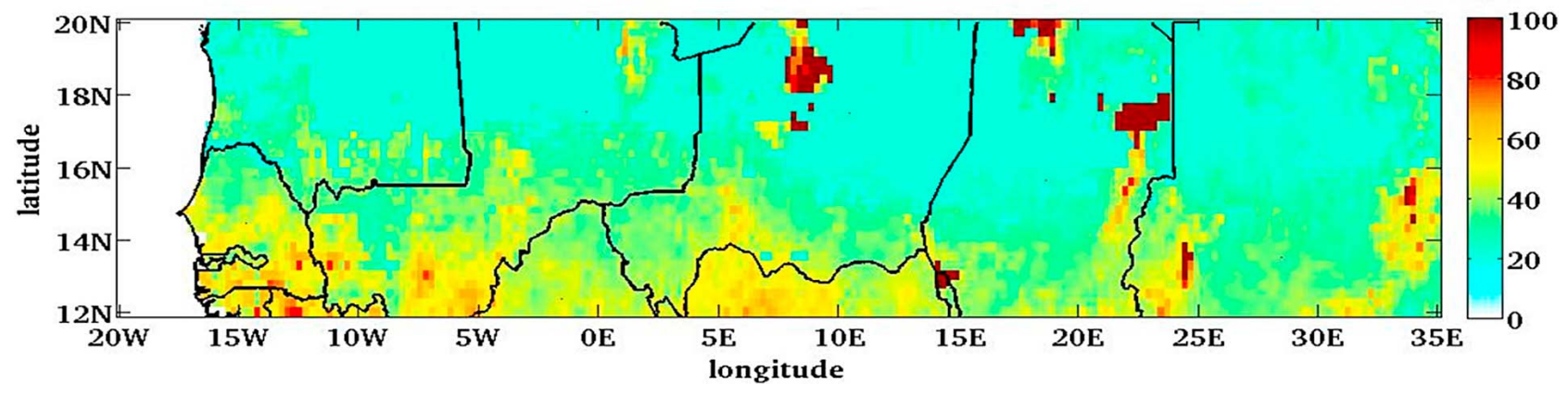

Figure 5. Minimum threshold wind friction velocities $U^{*}{ }_{t}$ (in $\mathrm{cm} \mathrm{s}^{-1}$ ) deduced from the roughness length derived from POLDER-1 measurements and completed from a geomorphologic analysis when necessary for year 2004 .

mainly in the north of the area) and 4 (in its southern part, i.e. between $12^{\circ} \mathrm{N}$ to $16^{\circ} \mathrm{N}$ ) (Figure 6). This increase of the surface soil moisture causes the threshold wind friction velocity to be 1 to 4 times higher than for a completely dry soil. The highest impact of the soil moisture on wind erosion thresholds is simulated in the south of the studied area at the core of the rainy season (between mid-July (DOY 200) and early September (DOY 250)). The impact of soil moisture on the wind erosion thresholds decreases rapidly at the end of the rainy period (end of October).

\subsubsection{Impact of the Herbaceous Vegetation}

[61] Figure 7 illustrates the combined impacts of soil moisture and vegetation dynamics on the threshold wind friction velocity. The grey cells correspond to cells where the wind erosion is totally inhibited by the presence of a
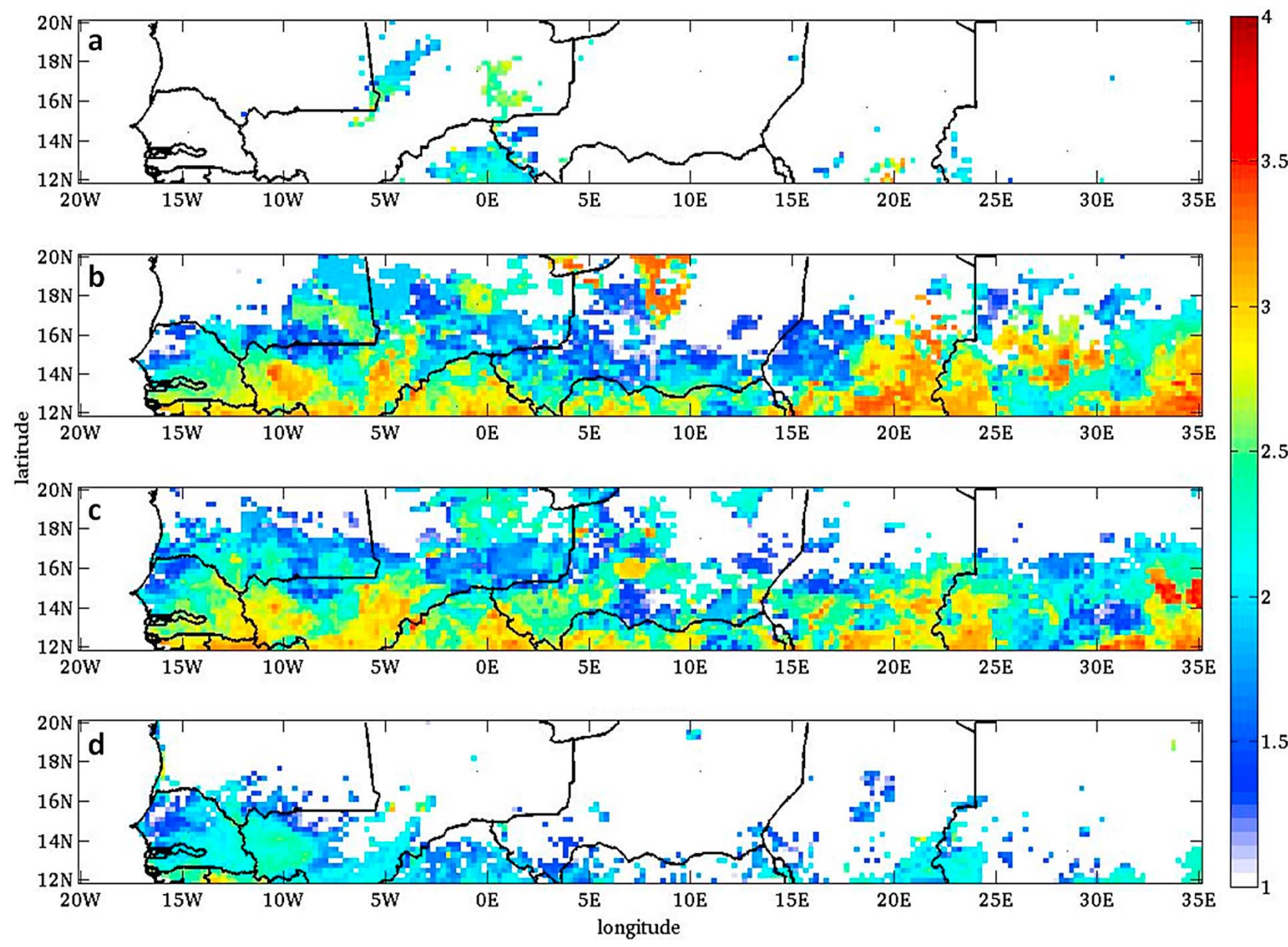

Figure 6. Ratio of the threshold wind friction velocity with and without soil moisture simulated by the STEP model run with the TRMM3B42 product as rainfall forcing at DOY (a) 100, (b) 200, (c) 250 and (d) 300 for year 2004 . 

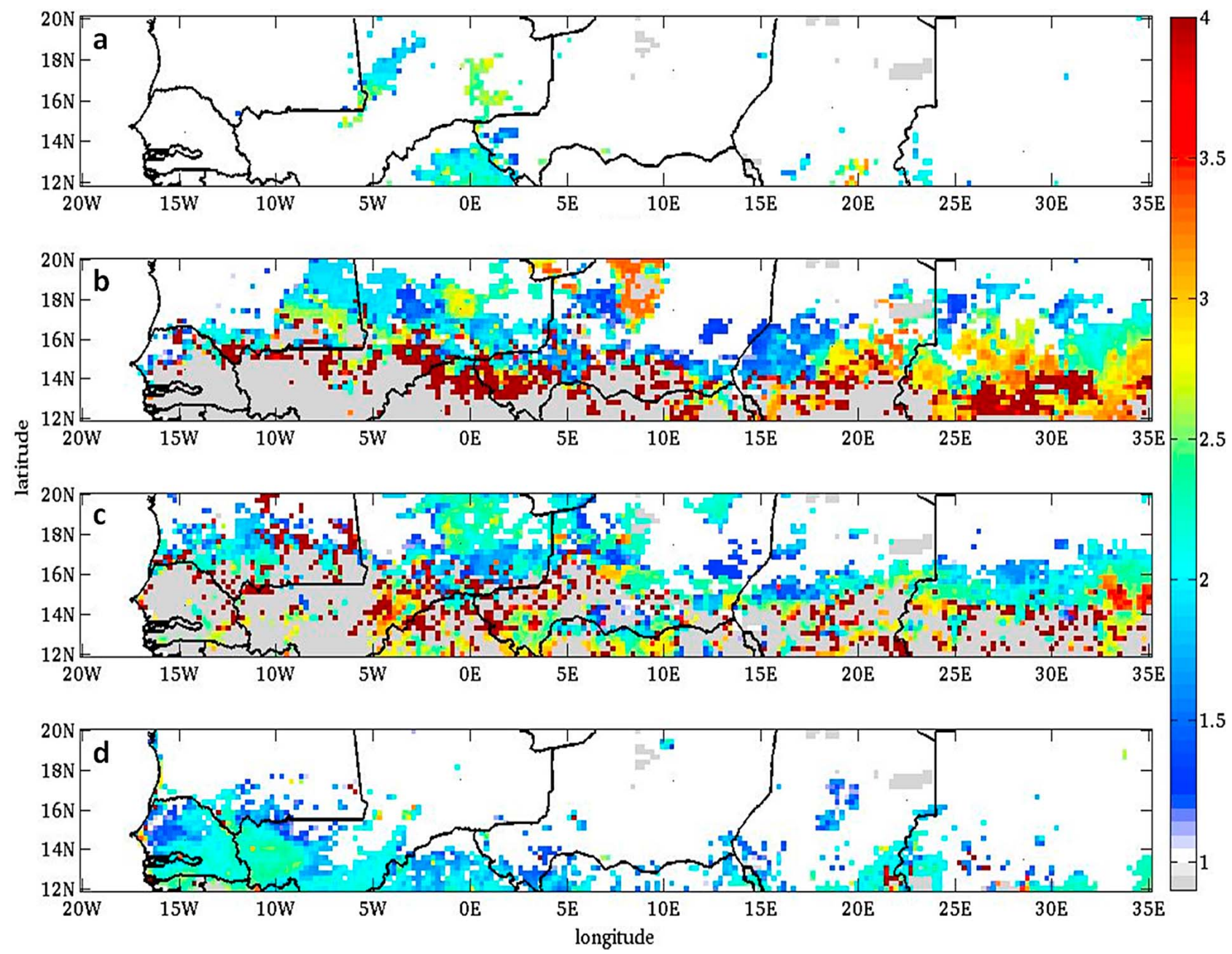

Figure 7. Ratio of the threshold wind friction velocity with and without herbaceous vegetation and soil moisture simulated by the STEP model run with the TRMM3B42 product as rainfall forcing at DOY (a) 100, (b) 200, (c) 250 and (d) 300 for year 2004.

dense vegetation (i.e., the fraction of the erodible surface $E^{\prime}$ becomes null).

[62] The variation of the ratio of the threshold wind friction velocities shows again a strong seasonal dynamics of the surface properties. Early April (DOY 100) corresponds to the dry season, without herbaceous vegetation and almost no surface soil moisture (see Figure 6). At mid-July (DOY 200), soil erosion is inhibited over a large southern part of the area because of the development of vegetation. At the end of September (DOY 300), green vegetation has disappeared, allowing erosion to occur if the wind is sufficiently strong. Thus, no dust emission can occur during this period of the year over the southern half of the area, whereas threshold wind friction velocities are unchanged over the northern half. Between these two zones, the increase ratios range between 1 and 4, and take much stronger values in a few grid cells (brown color; erosion is thus practically inhibited in these grid cells).

\subsection{Regional Simulations of Dust Emissions}

[63] Simulations of dust emissions have been performed over the area $20^{\circ} \mathrm{W}-35^{\circ} \mathrm{E}, 12^{\circ} \mathrm{N}-20^{\circ} \mathrm{N}$ for a 4-year period (2004-2007). As mentioned before, the temporal resolution of the wind database, and therefore of the dust emissions simulations, is 3 -hour and the spatial resolution is $0.25^{\circ}$. All simulated dust fluxes are vertical fluxes $F$ of particles having a diameter smaller than $20 \mu \mathrm{m}$. Two sets of simulations were performed, i.e. with and without accounting for the effect of soil moisture and vegetation dynamics as simulated from the STEP model.

[64] Figure 8 reports dust emissions (in Mt) and dust emission frequency (i.e. the number of simulated erosion events over the total number of 3-hour intervals - expressed in \%) as simulated for the year 2004 when the effects of soil moisture and vegetation dynamics are accounted for. The total annual dust emission over the area of interest is found to be $100 \mathrm{Mt}$. The main dust sources are located in three large structures located north of $15^{\circ} \mathrm{N}$, in agreement with the results of Middleton and Goudie [2001] and Laurent et al. [2008]: (1) the Mauritanian erg system called El Mreyye and the surrounding Holocene lakes $\left(18^{\circ} \mathrm{N}-20^{\circ} \mathrm{N}, 10^{\circ} \mathrm{W}-\right.$ $\left.5^{\circ} \mathrm{W}\right)$ [see Petit-Maire et al., 1983], (2) an area including the Bodele depression (Chad) and the great Bilma erg (Niger) $\left(15^{\circ} \mathrm{E}-20^{\circ} \mathrm{E}, 16^{\circ} \mathrm{N}-20^{\circ} \mathrm{N}\right)$, and to a lesser extent (relatively frequent but not very intense emissions) and (3) an area north of Sudan $\left(19^{\circ} \mathrm{N}-20^{\circ} \mathrm{N}, 25^{\circ} \mathrm{E}-35^{\circ} \mathrm{E}\right)$. This is consistent 

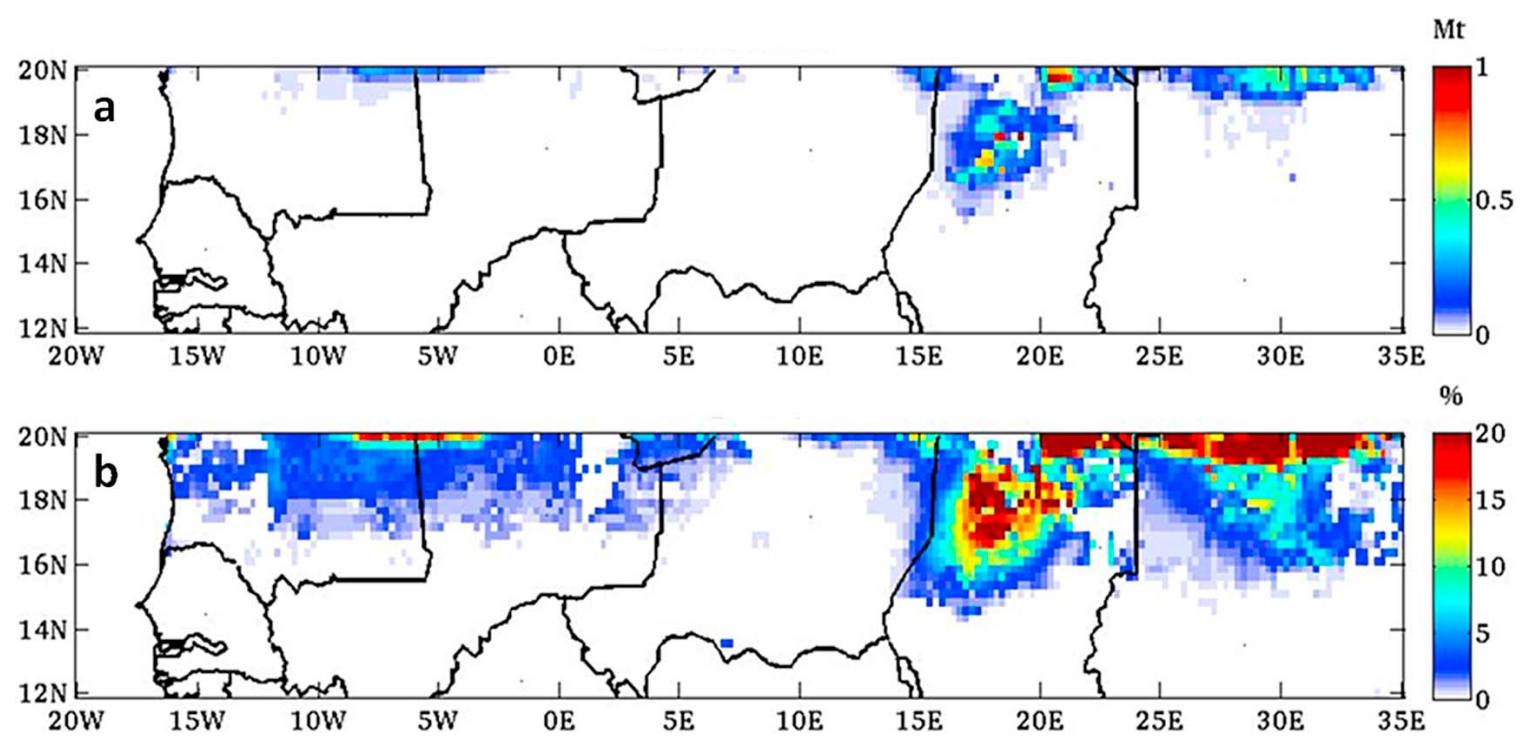

Figure 8. (a) Simulated annual dust emissions and (b) frequencies by the MB model taking into account soil moisture and vegetation seasonal dynamics estimated from the STEP model run with the TRMM3B42 product as rainfall forcing for year 2004.

with the Bodele depression being considered as the greatest dust source in the world [Prospero et al., 2002; Koren and Kaufman, 2004]. As shown in Figure 9, the simulated dust emissions for the years 2005, 2006 and 2007 show similar geographical patterns than for the year 2004, except that dust emission regions are much larger in 2007, and that frequency is lower in northern Sudan for this year.

[65] Table 1 reports the simulated annual dust emissions for the years 2004 to 2007, when seasonal dynamics of vegetation and surface soil moisture are or are not accounted for. Over the considered period, annual emissions without seasonal vegetation and soil moisture show a high interannual variability of $+/-115 \mathrm{Mt} /$ year, for an annual mean of $195 \mathrm{Mt} /$ year. This value is difficult to compare with previous simulations of Saharan dust emissions since the latter consider an area about 3 times larger. However, our results are compatible with those obtained by Callot et al. [2000] who estimated the mean annual dust emission for the central and western Sahara (north of $16^{\circ} \mathrm{N}$ ) to $760 \mathrm{Mt} /$ year (with +/-120 Mt of interannual variability) over the 1990-1992 period. Similarly, Laurent et al. [2008] computed a mean annual dust fluxes of $670 \mathrm{Mt} /$ year $(+/-60 \mathrm{Mt}$ of interannual variability) over the Saharan area $\left(16^{\circ} \mathrm{N}-38^{\circ} \mathrm{N}, 18^{\circ} \mathrm{W}-40^{\circ} \mathrm{E}\right)$ for the 1996-2001 period. Note that agreement with the estimations of the Saharan dust emissions mentioned above [Callot et al., 2000; Laurent et al., 2008] is even better for 2006 and 2007, when simulated dust emissions are greater.

[66] The differences between the two estimates (with/ without seasonal vegetation and soil moisture) illustrate how the increase of the threshold wind friction velocities due to the simulated seasonal dynamics of vegetation and surface soil moisture affects simulated dust emissions. The differences vary between $2 \mathrm{Mt}$ for year 2004 to $17 \mathrm{Mt}$ for year 2007 , and represent respectively $2 \%$ to $4.5 \%$ of the annual flux.

[67] The verisimilitude of the regional simulations is further checked by comparing them (Figure 9) to the UV Aerosol Index derived from the Ozone Monitoring
Instrument (OMI) onboard the NASA's Aura satellite (initially derived from the Total Ozone Mapping Spectrometer) [Herman et al., 1997; Torres et al., 1998] (Figure 10), and to the MODIS "Deep Blue" Aerosol Optical Depth (AOD) [Hsu et al., 2004, 2006] (Figure 11). This last product has been recently used to detect dust sources in West Africa by Ginoux et al. [2010], over an area $\left(0^{\circ} \mathrm{N}-20^{\circ} \mathrm{N}, 0^{\circ} \mathrm{E}-20^{\circ} \mathrm{E}\right)$ that partly overlap our simulation domain. As reminded by Schmechtig et al. [2011], these two satellite-derived products have some limitations: the UV Aerosol Index is sensitive to the aerosol layer altitude and thus may not produce the higher indexes at the exact source, whereas the Deep Blue AOD is available for non cloudy conditions only. Thus it is better to check the simulated sources by comparing them to both products. The simulated dust emissions (Figure 9) compared with satellite observations correspond to the case without soil moisture and seasonal vegetation, but as noticed above (see Table 1), their differences at regional scale are very small and thus do not bias this qualitative comparison.

[68] The simulations reproduce correctly the geographical locations of the principal dust sources (see Figure 8 and related text). They are consistent with the dust sources considered as natural sources retrieved by Ginoux et al. [2010]. The main point is that they also reproduce in a certain extent the interannual variability over the considered period (OMI indexes and Deep Blue AOD are indeed greater for year 2007, especially over the Bodele depression, as in the simulations). Yet, further comparisons are strongly limited. Firstly, advanced comparisons to satellite atmospheric dust load measurements or ground measurements would not be appropriate since the dust load in this region integrates dust transported in the Harmattan from the Sahara. Thus it is difficult to detect and to quantify the Sahelian signal beyond uncertainty level, especially given the uncertainty on the satellite products themselves. Secondly, the purpose of the present study is to represent dust emission fluxes from a "natural" Sahel: this situation does not correspond to the actual state of the Sahel. Strictly speaking, an advanced 

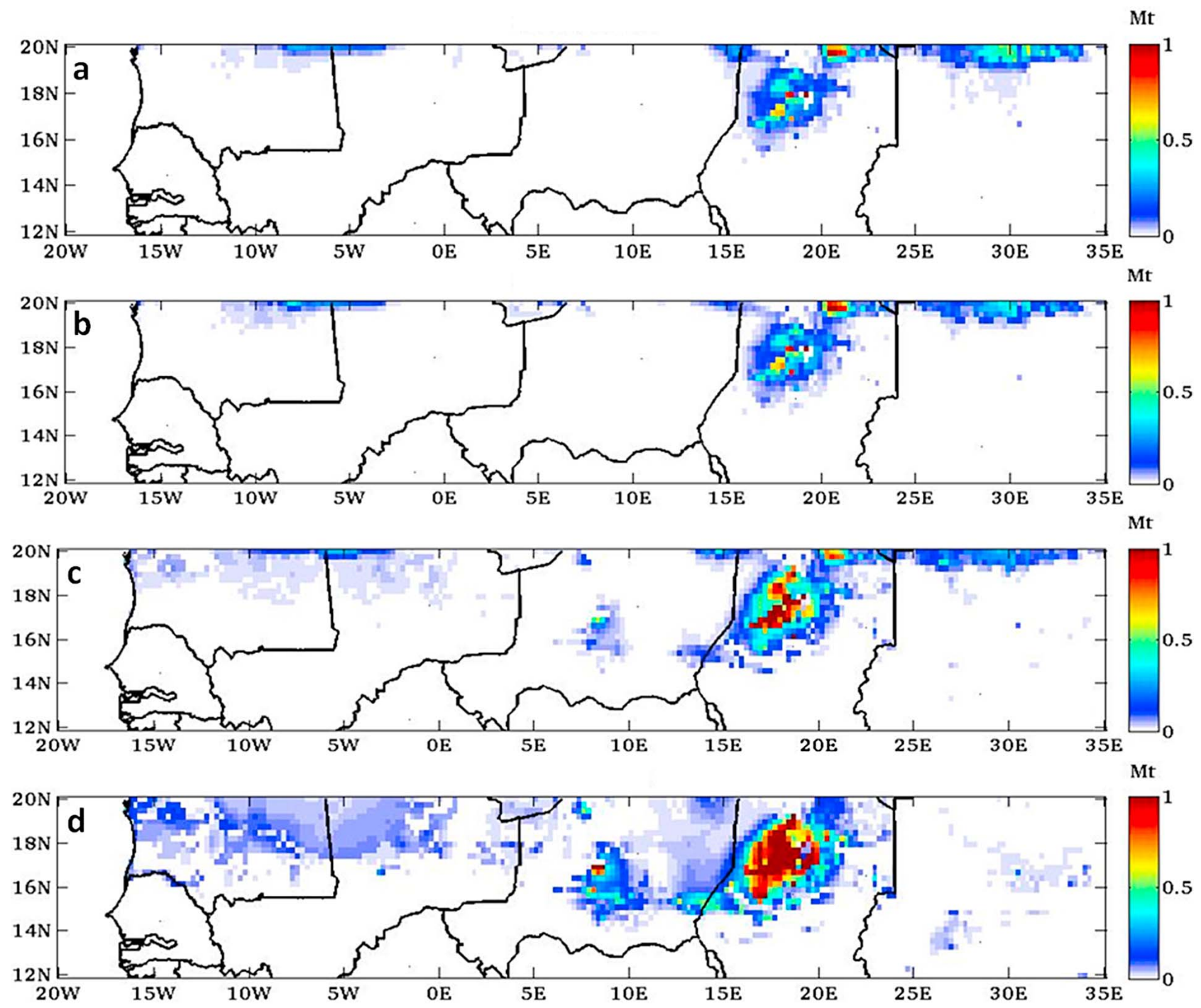

Figure 9. Simulated annual dust emissions by the MB model, taking into account soil moisture and vegetation seasonal dynamics estimated from the STEP model run with the TRMM3B42 product as rainfall forcing for years (a) 2004 (b), 2005, (c) 2006 and (d) 2007.

comparison with satellite observations could be performed only when anthropogenic pressure is integrated to the simulations. However, Figures 9-11 show that the simulated main dust sources are well located and that the interannual variability is well reproduced by the simulations. Furthermore, ground-based measurements of PM10 performed for years 2006 to 2008 in three stations located in Senegal, Mali and Niger [Marticorena et al., 2010] confirm that dust concentrations are significantly higher in 2007 compared to 2006.

[69] The inter-annual variability of the simulated dust fluxes can be due, in a certain extent, to the wind velocity fields. To check this hypothesis, the frequency of the strongest wind velocities (i.e. $>7 \mathrm{~m} \mathrm{~s}^{-1}$ ) for the 2 years exhibiting extrema annual flux over the considered period, i.e. 2004 and 2007, is reported in Figure 12. The threshold value of $7 \mathrm{~m} \mathrm{~s}^{-1}$ corresponds roughly to the lowest wind friction velocity for which wind erosion is simulated $\left(20 \mathrm{~cm} \mathrm{~s}^{-1}\right.$ for a roughness length $\mathrm{Z}_{0} \approx 1.10^{-3} \mathrm{~cm}$, following the logarithmic profile of $U^{*}$ according to Priestley [1959], and for neutral conditions of air density) (Figure 5). Thus, selecting the $10 \mathrm{~m}$ height wind velocities greater than $7 \mathrm{~m} \mathrm{~s}^{-1}$ insures that all the wind velocities strong enough to initiate wind erosion were accounted for.

[70] Whatever the considered year, the most frequent strong winds are located around the Bodele depression, the

Table 1. Simulated Annual Dust Emissions (in Mt) Over the Area of Interest $\left(12^{\circ} \mathrm{N}-20^{\circ} \mathrm{N}, 20^{\circ} \mathrm{W}-35^{\circ} \mathrm{E}\right)$ With and Without Taking Into Account the Seasonal Dynamics of Soil Moisture and of Vegetation Simulated by the STEP Model Run With the TRMM3B42 Product as Rainfall Forcing for Years 2004 to 2007

\begin{tabular}{ccc}
\hline Year & $\begin{array}{c}\text { Without Seasonal Vegetation, } \\
\text { Without Soil Moisture (Mt) }\end{array}$ & $\begin{array}{c}\text { With Seasonal Vegetation, } \\
\text { With Soil Moisture (Mt) }\end{array}$ \\
\hline 2004 & 102 & 100 \\
2005 & 99 & 95 \\
2006 & 196 & 187 \\
2007 & 382 & 365 \\
\hline
\end{tabular}



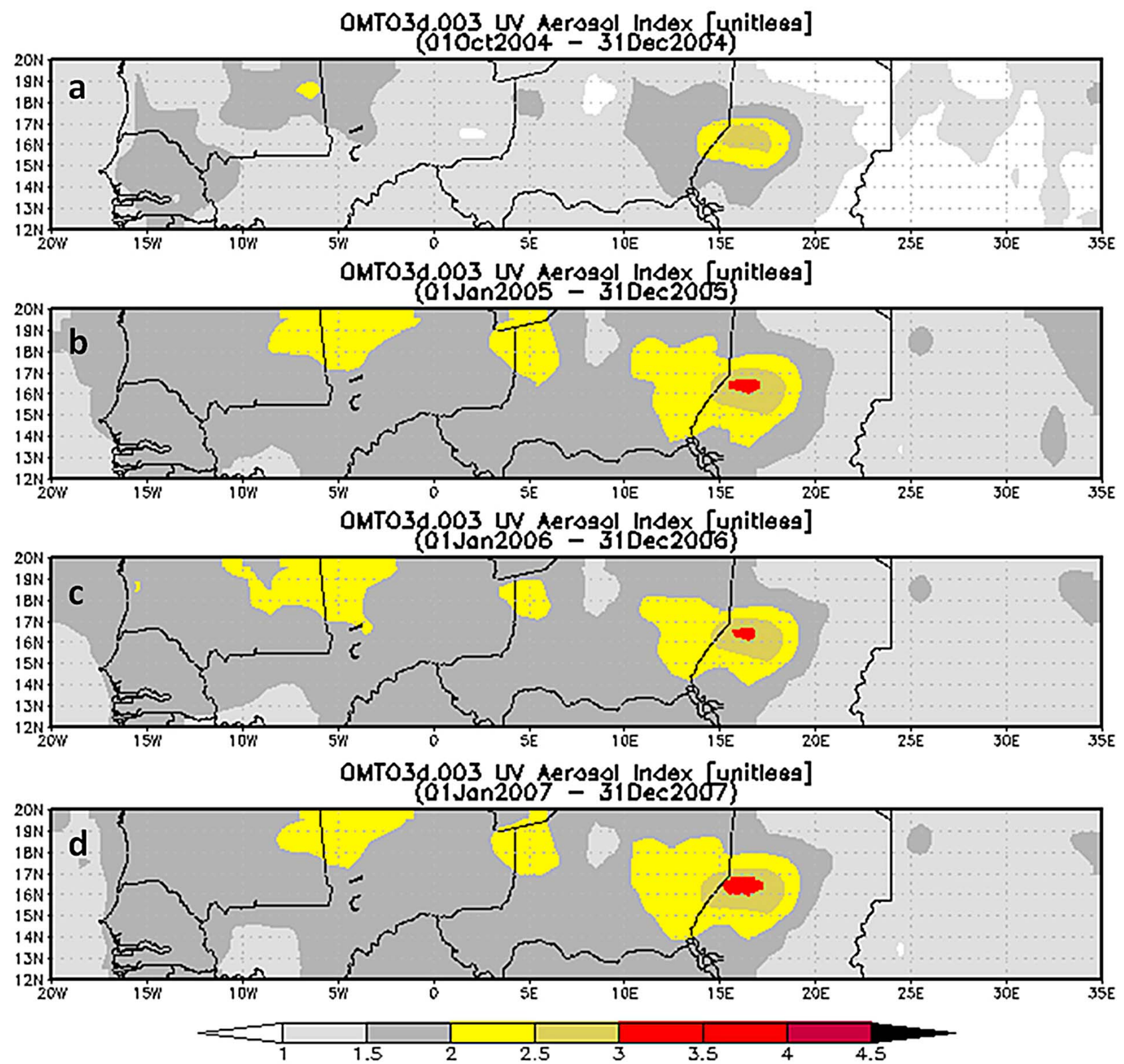

Figure 10. Annual mean UV Aerosol Index derived from OMI satellite observations for years (a) 2004 (b), 2005, (c) 2006 and (d) 2007, except for year 2004 when measurements started on 1 October.

Bilma erg and the El Mreyye erg. However, for 2007, wind velocities greater than $7 \mathrm{~m} \mathrm{~s}^{-1}$ cover a greater extent of the studied area. Their frequency of occurrence is also much higher. However, the high frequency of strong wind velocities observed over northern Sudan in 2004 does not appear anymore in 2007.

[71] Over the whole area, occurrences of ECMWF wind speed at $10 \mathrm{~m}$ height greater than $7 \mathrm{~m} \mathrm{~s}^{-1}$ are more numerous for 2007 than for 2004 (Figure 13). This is especially the case for wind speed (at $10 \mathrm{~m}$ height) between $7 \mathrm{~m} \mathrm{~s}^{-1}$ and $9 \mathrm{~m} \mathrm{~s}^{-1}$ : in 2007, occurrences of such wind speeds are about twice more numerous than for year 2004. These observations confirm the predominant role of the wind characteristics in the inter-annual variability of the simulated dust emissions.
[72] Finally, most of dust emissions occur over the northern half of the simulated area, where precipitation is low and the vegetation cover is extremely weak or even null. It is therefore difficult to quantify the impacts of soil moisture and herbaceous vegetation on dust emissions when considering the whole simulated area. Indeed, dust emission simulation performed over the same area as for the year 2004 , but for a dry and bare soil, yields to annual dust flux of $102 \mathrm{Mt}$, not very different from the $100 \mathrm{Mt}$ obtained when taking into account these two phenomena (Table 1). The same behavior is observed for years 2005 to 2007: for the whole area, the erosion inhibition (i.e. the difference between dust emissions with and without soil moisture and seasonal vegetation) is very weak (between 2 and $4.5 \%$ ). 

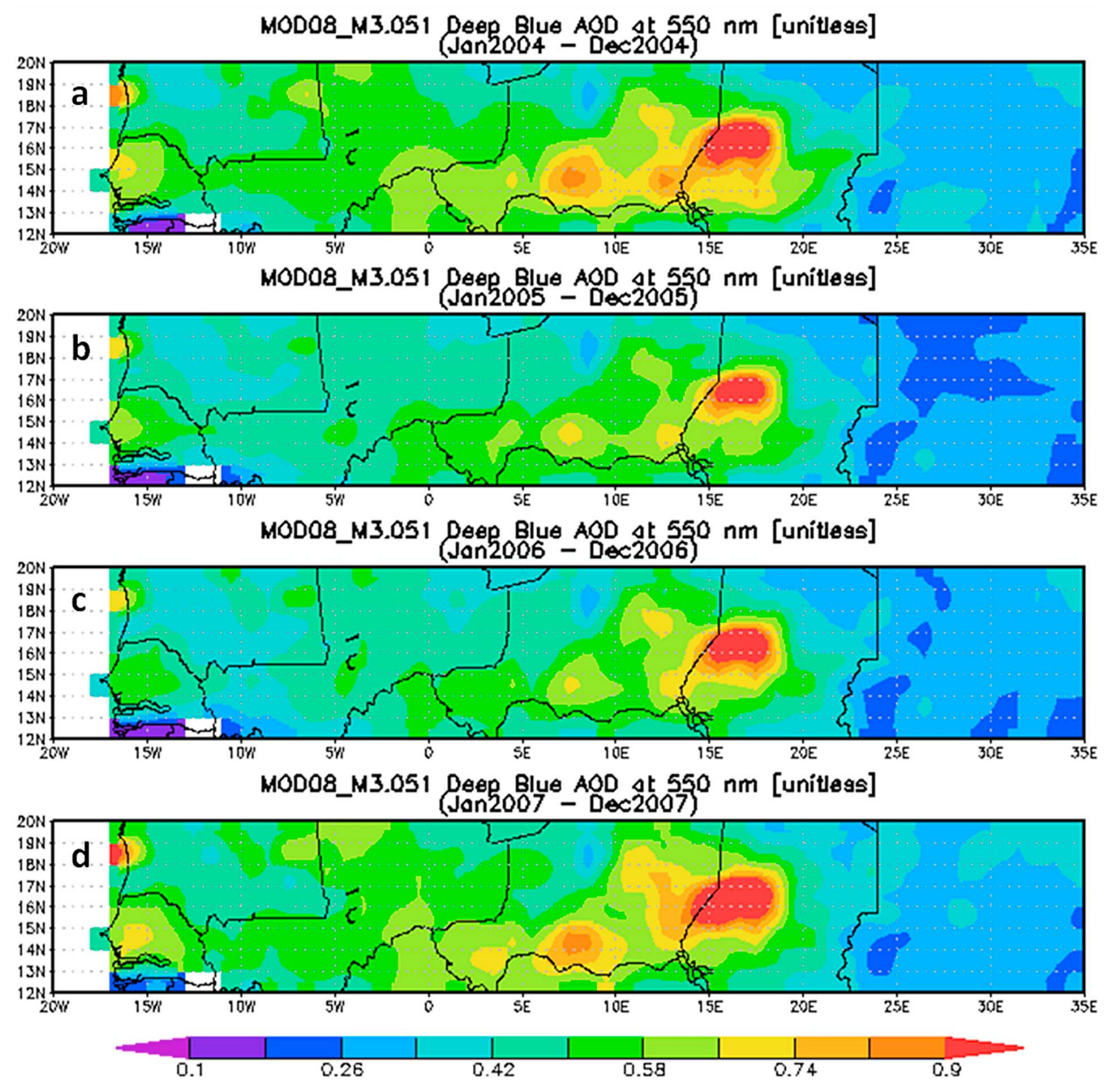

Figure 11. Annual mean MODIS Deep Blue Aerosol Optical Depth (AOD) for years (a) 2004 (b), 2005 , (c) 2006 and (d) 2007 .

\subsection{Inhibition due to the Seasonal Dynamics of Soil Moisture and Herbaceous Vegetation}

[73] In order to better quantify the impacts of soil moisture and herbaceous vegetation on dust emissions, the considered zone has been limited to the area where the vegetation develops. The following methodology is applied, as illustrated for year 2007 in Figure 14:

[74] Only are retained the grid cells satisfying two conditions: (1) the annual simulated dust emission flux is not null for simulation without soil moisture and without seasonal vegetation and (2) seasonal vegetation develops according to the STEP model simulations (i.e., the vegetation cycle reaches at least a LAI equal to $0.3 \mathrm{~m}^{2} / \mathrm{m}^{2}$, which is the offset value for dry season [see Fensholt et al., 2004]).

[75] Combining these two conditions yields to a "combined mask" defining a fringe where wind erosion occurs and where herbaceous vegetation develops. This fringe shows a slight north-west/south-east orientation, and becomes thinner to its south-eastern edge. Since the fringe depends on the wind velocity field and on the vegetation cover, its extent and its localization is year-dependent. Yet, the same characteristics are observed for the 4 simulated years: the most remarkable pattern is that the fringe is approximately located in the Sahelian area stricto sensu, i.e. 


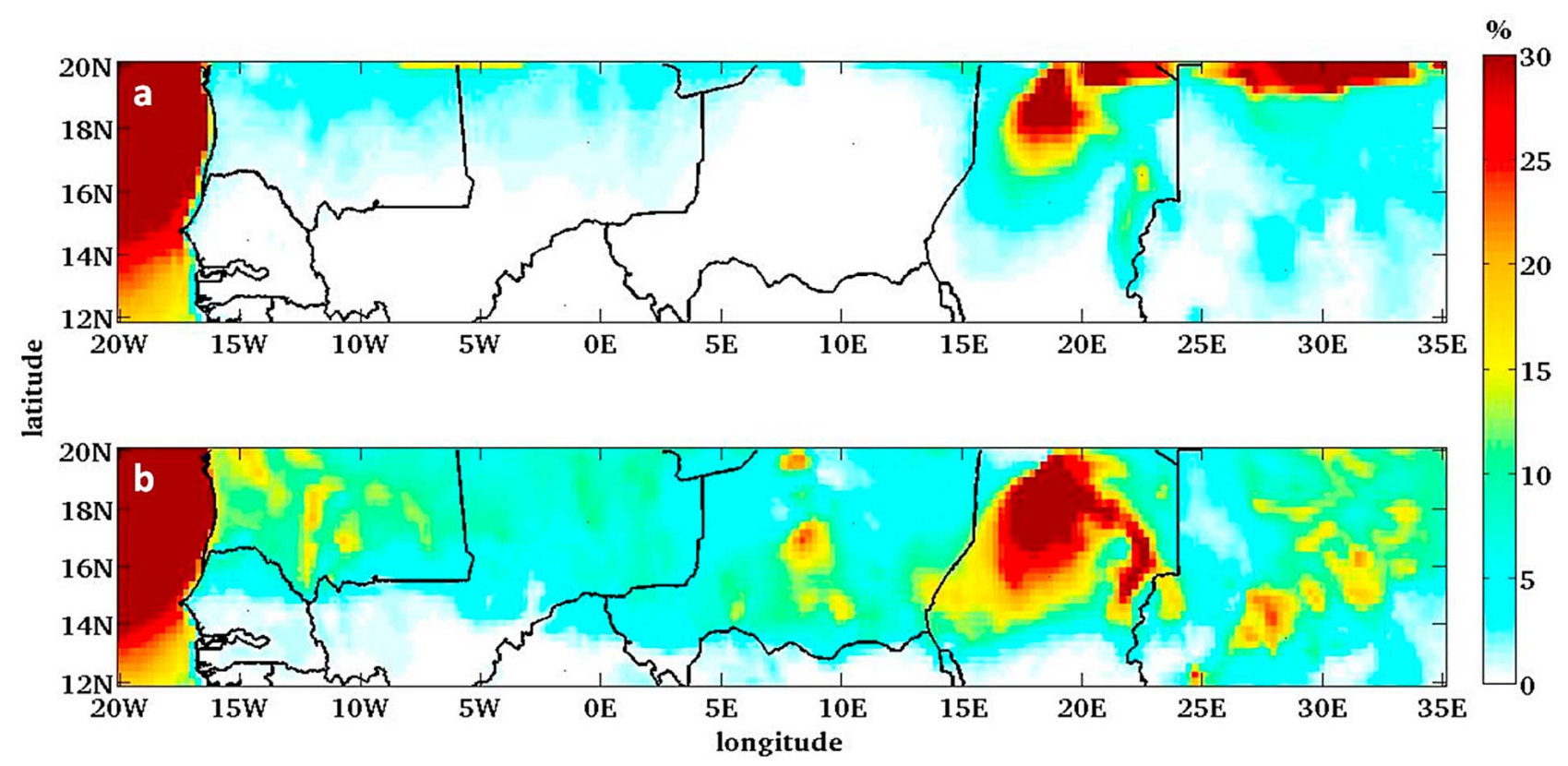

Figure 12. Frequency (in \%) of ECMWF wind speed at $10 \mathrm{~m}$ height greater than $7 \mathrm{~m} \mathrm{~s}^{-1}$ for years (a) 2004 and (b) 2007.

the region where precipitations range between 200 and 600 mm/year [see, e.g., Lebel and Ali, 2009].

[76] Rainfall characteristics are not very different over the studied years; therefore the location of the northern edge of the fringe does not vary significantly over the simulated years. Additionally, the strong winds occur mainly in the northern part of the studied area and they are getting less frequent southward (Figure 12). In other words, the rainfall characteristics mostly determine the location of the northern border of the fringe, while the wind velocity fields drive the location of its southern edge. In case of a severe drought, vegetation would not develop as far north and, assuming the wind pattern remains the same as observed here, the fringe would thus be probably located further south.

[77] A budget of the impact of soil moisture and herbaceous vegetation on simulated annual dust emissions has been established over the fringe by computing the difference between annual dust emissions simulated in the case of a "dry bare soil" minus those obtained in the case of a "wet vegetated soil". An inhibition effect can then be easily computed (Table 2).

[78] Simulated annual dust emissions from the fringe are much stronger for 2007 ( 20 Mt) than for the 3 previous years. Erosion inhibition (i.e. difference in dust emissions between simulations without and with the effects of soil moisture and seasonal vegetation) varies between $20 \%$ (in 2007 ) and $35 \%$ (in 2005). Note how the extent and the location of the fringe vary with years (Figure 15), since its northern edge is mainly determined by the vegetation development, while its southern edge mostly depends on the wind velocity field. Stronger winds in 2007 yield to a wider and more continuous fringe than in 2004, 2005, and 2006. Particularly, a zone of dust emissions, not observed for years 2004 and 2005 , appears between $5^{\circ} \mathrm{W}$ and $15^{\circ} \mathrm{E}$. This zone corresponds to an area where the wind velocity was strong enough in 2007 to initiate erosion but not in 2004 (see Figure 12). This change in the extent of the fringe, from $2.110^{5} \mathrm{~km}^{2}$ in 2004 to $9.910^{5} \mathrm{~km}^{2}$ in 2007 , strongly affects the simulated dust emissions (Table 2).

[79] The seasonal dynamics of dust emissions over the fringe is illustrated in Figure 16 for 2007 on a 10-day basis. One can notice that it does not change between the cases with and without soil moisture and seasonal vegetation. In the case of a "dry and bare surface", the largest dust emissions are simulated at the beginning of the year, i.e. during the dry season (especially at the beginning of January, March and May) (Figure 16a). Then dust emissions decrease before reaching again high values in June, at the

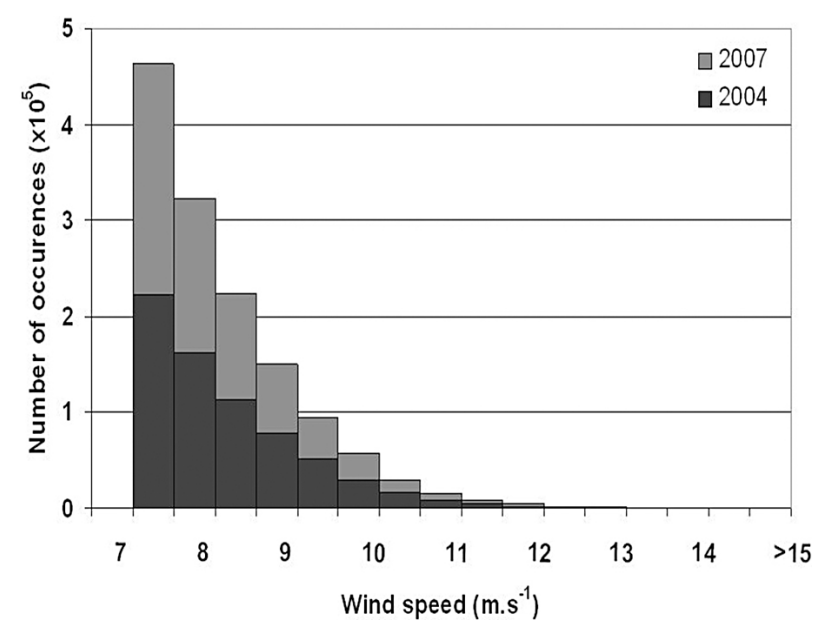

Figure 13. Distribution of ECMWF wind speed at $10 \mathrm{~m}$ height greater than $7 \mathrm{~m} \mathrm{~s}^{-1}$ for years 2004 and 2007. 

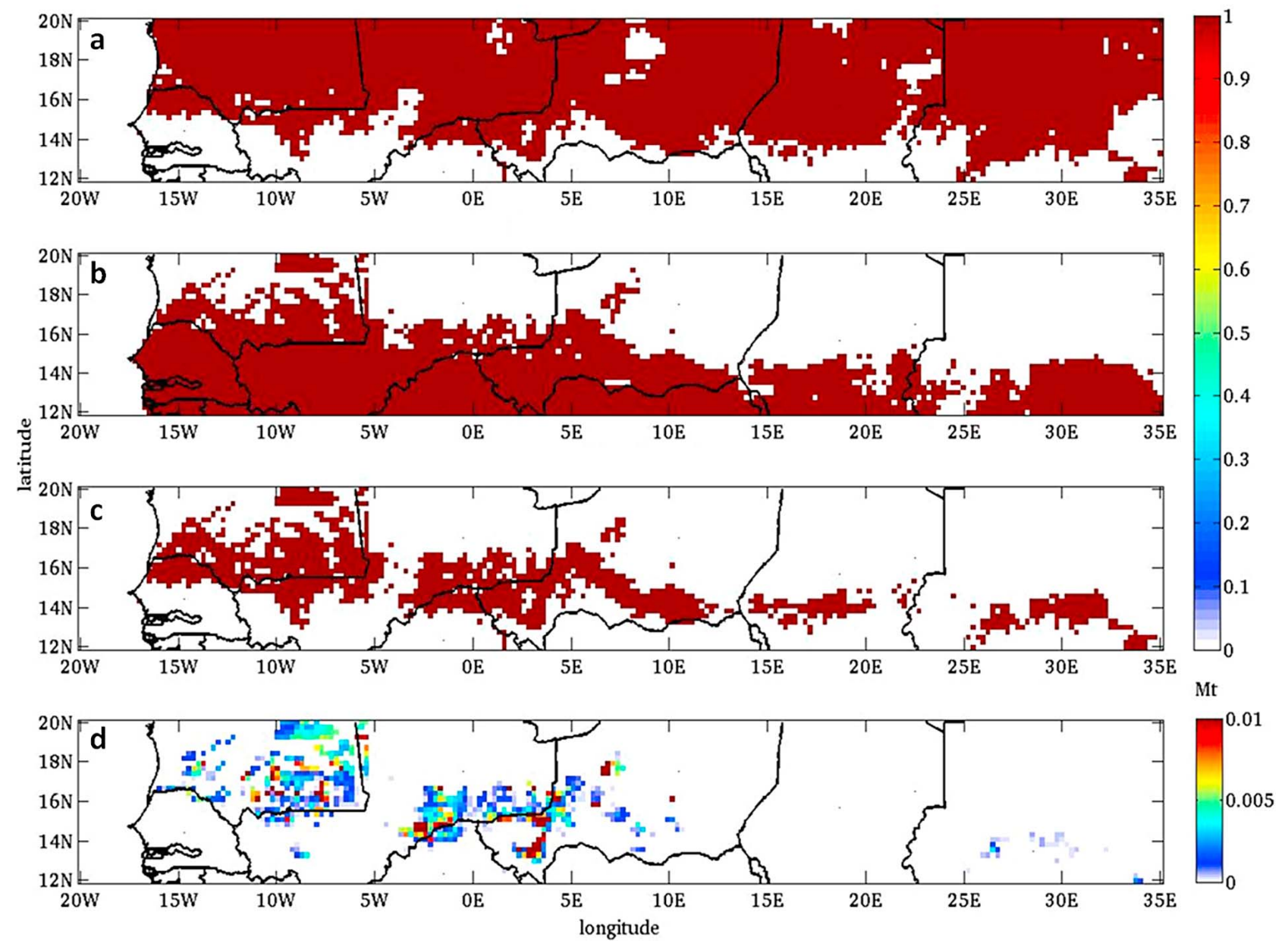

Figure 14. For year 2007, (a) mask for non-null annual simulated dust emission flux by the MB model without soil moisture and without herbaceous vegetation; (b) mask for herbaceous vegetation cycle simulated by the STEP model run with the TRMM3B42 product as rainfall forcing; (c) combination of the two first masks; and (d) annual dust emission budget on the defined fringe between the cases with and without soil moisture and herbaceous vegetation.

beginning of the rainy season, and in the middle of July. Dust emissions are low at the core of the rainy season (from August to October). At the end of the year, dry season restarts and dust emissions become important again (particularly in November). In the case of a "wet and vegetated surface", the dynamics pattern (Figure 16b) is similar as for a "dry and bare surface". Yet, emissions are partly inhibited. At the core of the rainy season (between late June and midJuly; Figure 16c), they are totally inhibited by the vegetation cover (see Figure 7).

[80] These results are in agreement with the measurements of PM10 for years 2006 to 2008 in three stations located in Senegal, Mali and Niger [Marticorena et al., 2010]: the highest concentrations were observed during the dry season (particularly around December and April) and at the beginning of the rainy season (June). These high dust concentrations observed at the beginning of the rainy season are considered by Marticorena et al. [2010] due to local dust emissions: at this period, local wind velocities are strong enough to initiate erosion.

[81] Few observations are available to further check the quality of these simulations. The good consistency of regional simulated dust emissions has been checked by comparisons to observations at different steps of the simulations (rainfall forcing, simulated vegetation, surface roughness, and simulated regional dust emissions). Dust observations and measurements have been compared to simulated regional emissions regarding the location of the main dust sources (section 3.2, Figures 9-11) and dynamics from annual to seasonal time scales (section 3.2 and this

Table 2. Simulated Annual Dust Emissions Over the Fringe With and Without Taking Into Account the Seasonal Dynamics of Soil Moisture and of Vegetation Simulated by the STEP Model Run With the TRMM3B42 Product as Rainfall Forcing for Years 2004 to 2007

\begin{tabular}{ccccc}
\hline Year & $\begin{array}{c}\text { Dry Bare } \\
\text { Soil (Mt) }\end{array}$ & $\begin{array}{c}\text { Wet Vegetated } \\
\text { Soil (Mt) }\end{array}$ & $\begin{array}{c}\text { Mass } \\
\text { Inhibition }\end{array}$ & $\begin{array}{c}\text { Surface of the } \\
\text { Fringe }\left(\mathrm{km}^{2}\right)\end{array}$ \\
\hline 2004 & 0.7 & 0.5 & $29 \%$ & $2.110^{5}$ \\
2005 & 4.6 & 3.0 & $35 \%$ & $3.010^{5}$ \\
2006 & 5.2 & 3.8 & $32 \%$ & $5.310^{5}$ \\
2007 & 20.5 & 16.3 & $20 \%$ & $9.910^{5}$ \\
\hline
\end{tabular}




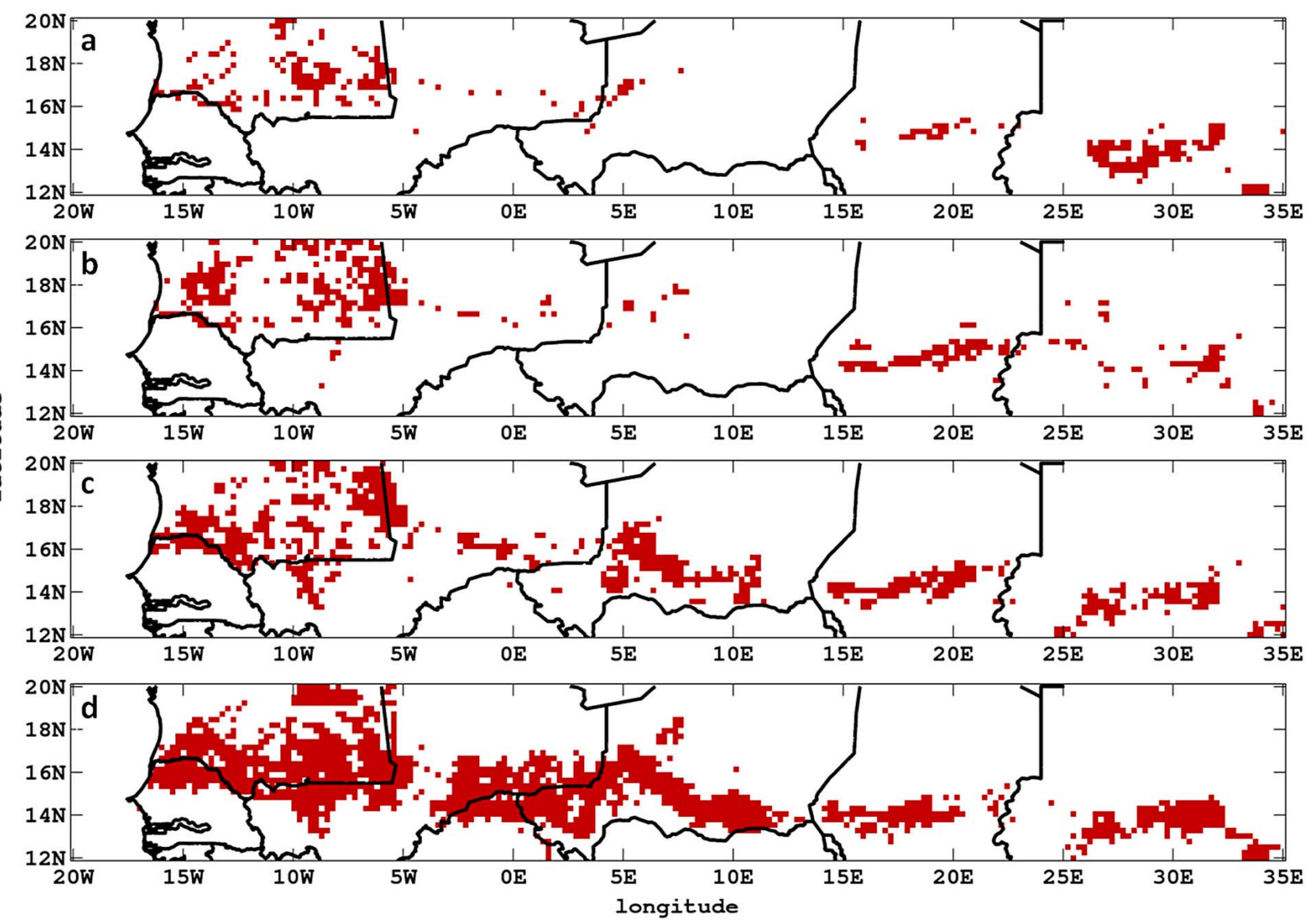

Figure 15. Fringe where seasonal vegetation is simulated by the STEP model run with the TRMM 3 B42 as rainfall forcing and where dust emission is simulated for years (a) 2004 (b), 2005, (c) 2006 and (d) 2007.
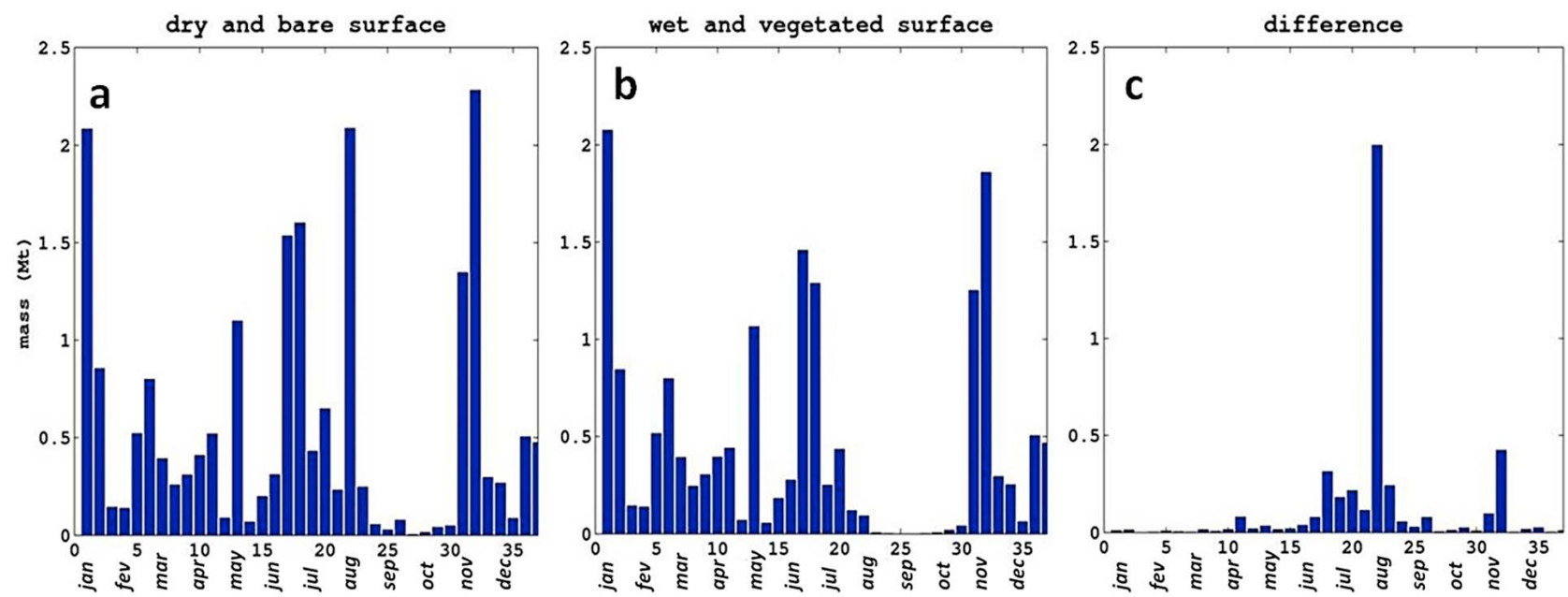

Figure 16. Temporal distribution (on a 10-days basis, indicated also in months) of the simulated dust emissions over the fringe (a) without soil moisture and seasonal vegetation; (b) with soil moisture and herbaceous vegetation; and (c) of the difference for year 2007. 
subsection). These comparisons suggested the good verisimilitude of the regional results. Although the last results dealing with dust emission and inhibition over the defined fringe cannot be validated in the same way, the good consistency of the simulated vegetation and of roughness values suggest a satisfying confidence level in these final diagnoses.

\section{Conclusion}

[82] A modeling approach has been developed to address the challenging issue of dust emissions from the Sahelian semi-arid area to the atmosphere. Two specific models have been associated: the STEP vegetation model [Mougin et al., 1995] has been used to reproduce the growth and death of the seasonal herbaceous layer, and the MB dust emission model [Marticorena and Bergametti, 1995] has been used to compute dust emissions.

[83] Rainfall is known to be the most sensitive parameter for simulating Sahelian vegetation. The TRMM3B42 product was selected as input data for the STEP model according to an intercomparison of satellite-based rainfall products performed over the Sahel, and the simulated vegetation has been validated by comparison to MODIS satellite observations [Pierre et al., 2011]. Then, an empirical parameterization was used to estimate the continuous change in the surface roughness induced by the simulated vegetation. The obtained values are in good agreement with the few existing field measurements. "Static" (i.e., constant in time) surface properties are based on the POLDER-1 satellite measurements and on previous studies [Marticorena et al., 2004; Laurent et al., 2008].

[84] The annual dust emissions over the regions extending from $12^{\circ} \mathrm{N}$ to $20^{\circ} \mathrm{N}$ and from $20^{\circ} \mathrm{W}$ to $35^{\circ} \mathrm{E}$ were estimated over the period 2004-2007. They range between $100 \mathrm{Mt}$ in 2004 to $400 \mathrm{Mt}$ in 2007. Their geographic pattern is in good agreement with the OMI UV Aerosol Index and MODIS Deep Blue AOD; their interannual variability is also consistent with these satellite observations and with Marticorena et al. [2010] ground-based measurements. Most of the dust emissions are located in the northern part of the simulated region which is not affected by seasonal precipitations and vegetation growth.

[85] To specifically assess the impacts of the seasonal and interannual dynamics of soil moisture and seasonal vegetation on Sahelian dust emissions, the simulated area was restrained to a smaller fringe where both wind erosion and herbaceous vegetation can interact. Over this fringe, which extent and location depend on the wind velocity and on the vegetation development, annual dust emissions range between $0.5 \mathrm{Mt}$ to $20 \mathrm{Mt}$. Inhibition of dust emissions resulting from these two phenomena varies between $20 \%$ and $35 \%$, depending on the year. The contribution of this specific area to the global dust load is low, especially when comparing with the Saharan dust emissions which have been estimated to be about $670 \mathrm{Mt}$ year ${ }^{-1}$ [Laurent et al., 2008]. Our results reveal also how strong can be the impact of soil moisture and vegetation cover on dust emissions: simulated dust emissions are totally inhibited at the core of the rainy season over the defined fringe because of these two factors.

[86] Ongoing research will focus on sensitivity tests and new relationships to better infer the surface properties (especially roughness length) from the characteristics of the simulated vegetation. Following studies must also aim at estimating the contribution of "anthropogenic" dust sources that would combine with the "natural" contribution estimated here, by localizing and taking into account cultivated areas and pasture, with their specific vegetation cycle and surface dynamics. Indeed, this study does not account for dust emissions associated to land use like cultivation and pasture. Only dust emissions from an undisturbed Sahel were simulated here. The results strongly suggest that an undisturbed Sahel is not a major dust source (a maximum of $20 \mathrm{Mt} \mathrm{year}^{-1}$ are emitted from the fringe where seasonal vegetation grows). This is in agreement with observations performed by Rajot [2001] in Niger which show that wind erosion is noticeably more important on cultivated fields than on naturally vegetated areas. More generally, several studies pointed out the importance of wind erosion on cultivated and grazed surfaces in arid and semi-arid regions [e.g., Bielders et al., 2000; Hoffmann et al., 2008; López et al., 2000]. Thus, a methodology accounting for the effects of Sahelian agricultural activities on the surface properties has to be developed. These estimations should be compared to the present simulations in order to evaluate how much the dust emissions in the Sahel are affected by the human activities.

[87] Acknowledgments. We would like to thank the Centre National d'Etudes Spatiales (CNES) for supporting the present research. We also thank Marielle Gosset for the reading of this manuscript, and J.-L. Roujean for providing the MODIS albedo dataset used as input in the vegetation model. Based on a French initiative, AMMA was built by an international scientific group and is currently funded by a large number of agencies, especially from France, UK, US and Africa. It has been the beneficiary of a major financial contribution from the European Community's Sixth Framework Research Programme. Detailed information on scientific coordination and funding is available on the AMMA international website: http://www. amma-international.org. Analyses and visualizations used in this paper (Figures 10 and 11) were produced with the Giovanni online data system, developed and maintained by the NASA GES DISC. We acknowledge the mission (MODIS, OMI) scientists and Principal Investigators who provided the data used in this research effort.

\section{References}

Abdourhamane Touré, A., J. L. Rajot, Z. Garba, B. Marticorena, C. Petit, and D. Sebag (2011), Impact of very low crop residues cover on wind erosion in the Sahel, Catena, 85, 205-214, doi:10.1016/j.catena.2011.01.002.

Alfaro, S. C., and L. Gomes (2001), Modeling mineral aerosol production by wind erosion: Emission intensities and aerosol distributions in source areas, J. Geophys. Res., 106, 18,075-18,084, doi:10.1029/2000JD900339.

Anyamba, A., and C. J. Tucker (2005), Analysis of Sahelian vegetation dynamics using NOAA-AVHRR NDVI data from 1981-2003, J. Arid Environ., 63, 596-614, doi:10.1016/j.jaridenv.2005.03.007.

Bagnold, R. A. (1941), The Physics of Blown Sand and Desert Dunes, 265 pp., Methuen, London.

Bégué, A. (1991), Estimation de la production primaire en zone sahélienne à partir de données radiométriques. Cas d'un couvert discontinu: le mil, Doctorat, 140 pp., Univ. Paris 7, Paris.

Bielders, C., K. Michels, and J. L. Rajot (2000), On-farm evaluation of ridging and residue management practices to reduce wind erosion in Niger, Soil Sci. Soc. Am. J., 64, 1776-1785, doi:10.2136/sssaj2000.6451776x.

Callot, Y., B. Marticorena, and G. Bergametti (2000), Geomorphologic approach for modelling the surface features of arid environments in a model of dust emissions: Application to the Sahara desert, Geodin. Acta, 13, 245-270, doi:10.1016/S0985-3111(00)01044-5.

Chatenet, B., B. Marticorena, L. Gomes, and G. Bergametti (1996), Assessing the microped size distributions of desert soils erodible by wind, Sedimentology, 43, 901-911, doi:10.1111/j.1365-3091.1996.tb01509.x.

Chepil, W. S. (1951), Properties of soil which influence wind erosion: IV. State of dry aggregate structure, Soil Sci., 72, 387-402, doi:10.1097/ 00010694-195111000-00007.

Colarco, P. R., O. B. Toon, O. Torres, and F. J. Rasch (2002), Determining the UV imaginary part of refractive index of Saharan dust particles from TOMS data and a three dimensional model of dust transport, J. Geophys. Res., 107(D16), 4289, doi:10.1029/2001JD000903. 
Darmenova, K., I. N. Sokolik, Y. Shao, B. Marticorena, and G. Bergametti (2009), Development of a physically based dust emission module within the Weather Research and Forecasting (WRF) model: Assessment of dust emission parameterizations and input parameters for source regions in Central and East Asia, J. Geophys. Res., 114, D14201, doi:10.1029/ 2008JD011236.

Fécan, F., B. Marticorena, and G. Bergametti (1999), Parameterization of the increase of the aeolian erosion threshold wind friction velocity due to soil moisture for semi arid areas, Ann. Geophys., 17, 149-157.

Fensholt, R., I. Sandholt, and M. Schultz Rasmussen (2004), Evaluation of MODIS LAI, fAPAR and the relation between fAPAR and NDVI in a semiarid environment using in situ measurements, Remote Sens. Environ., 91, 490-507, doi:10.1016/j.rse.2004.04.009.

Gillette, D. A. (1974), On the production of soil wind erosion aerosols having the potential for long range transport, J. Atmos. Res., 8, 735-744.

Ginoux, P., M. Chin, I. Tegen, J. M. Prosper, B. Holben, O. Dubovik, and S.-J. Lin (2001), Sources and distributions of dust aerosols simulated with the GOCART model, J. Geophys. Res., 106(D17), 20,255-20,273, doi:10.1029/ 2000JD000053.

Ginoux, P., D. Garbuzov, and N. C. Hsu (2010), Identification of anthropogenic and natural dust sources using Moderate Resolution Imaging Spectroradiometer (MODIS) Deep Blue level 2 data, J. Geophys. Res., 115 , D05204, doi:10.1029/2009JD012398.

Greeley, R., and J. D. Iversen (1985), Wind as a Geological Process, 333 pp., Cambridge Univ. Press, Cambridge, U. K. doi:10.1017/ CBO9780511573071.

Herman, J. R., P. K. Bhartia, O. Torres, C. Hsu, C. Seftor, and E. Celarier (1997), Global distribution of UV-absorbing aerosols from Nimbus7/TOMS data, J. Geophys. Res., 102, 16,911-16,922, doi:10.1029/96JD03680.

Hiernaux, P., E. Mougin, L. Diarra, N. Soumaguel, F. Lavenu, Y. Tracol, and M. Diawara (2009), Rangeland response to rainfall and grazing pressure over two decades: Herbaceous growth pattern, production and species composition in the Gourma, Mali, J. Hydrol., 375(1-2), 114-127.

Hoffmann, C., R. Funk, R. Wieland, Y. Li, and M. Sommer (2008), Effects of grazing and topography on dust flux and deposition in the Xilingele grassland, Inner Mongolia, J. Arid Environ., 72, 792-807, doi:10.1016/ j.jaridenv.2007.09.004.

Hsu, N. C., S.-C. Tsay, M. D. King, and J. R. Herman (2004), Aerosol properties over bright-reflecting source regions, IEEE Trans. Geosci. Remote Sens., 42(3), 557-569, doi:10.1109/TGRS.2004.824067.

Hsu, N. C., S.-C. Tsay, M. D. King, and J. R. Herman (2006), Deep blue retrievals of Asian aerosol properties during ACE-Asia, IEEE Trans. Geosci. Remote Sens., 44(11), 3180-3195, doi:10.1109/TGRS.2006.879540.

Huffman, G. J., R. F. Adler, D. T. Bolvin, G. Gu, E. J. Nelkin, K. P. Bowman, Y. Hong, E. F. Stocker, and D. B. Wolff (2007), The TRMM Multisatellite Precipitation Analysis (TMPA): Quasi-global, multiyear, combined-sensor precipitation estimates at fine scales, J. Hydrometeorol., 8, 38-55, doi:10.1175/JHM560.1.

Intergovernmental Panel on Climate Change (IPCC) (2007), Climate Change 2007: The Physical Science Basis. Contribution of Working Group I to the Fourth Assessment Report of the IPCC, Cambridge Univ. Press, Cambridge, U. K.

Iversen, J. D., and B. R. White (1982), Saltation threshold on Earth, Mars and Venus, Sedimentology, 29, 111-119, doi:10.1111/j.1365-3091.1982. tb01713.x.

Jickells, T. D., et al. (2005), Global iron connections between desert dust, ocean biogeochemistry, and climate, Science, 38(5718), 67-71, doi:10.1126/ science. 1105959

Justice, C. O., J. R. G. Townshend, N. Holben, and C. J. Tucker (1985), Analysis of the phenology of global vegetation using meteorological satellite data, Int. J. Remote Sens., 6, 1271-1318, doi:10.1080 01431168508948281

King, J., W. G. Nickling, and J. A. Gillies (2005), Representation of vegetation and other non erodible elements in Aeolian shear stress partitioning models for predicting transport threshold, J. Geophys. Res., 110, F04015, doi:10.1029/2004JF000281.

Kok, J. F. (2011), A scaling theory for the size distribution of emitted dust aerosols suggests climate models underestimate the size of the global dus cycle, Proc. Natl. Acad. Sci. U. S. A., 108, 1016-1021, doi:10.1073/ pnas. 1014798108

Koren, I., and Y. J. Kaufman (2004), Direct wind measurements of Saharan dust events from Terra and Aqua satellites, Geophys. Res. Lett., 31 L06122, doi:10.1029/2003GL019338.

Laurent, B., B. Marticorena, G. Bergametti, P. Chazette, F. Maignan, and C. Schmechtig (2005), Simulation of the mineral dust emission frequencies from desert areas of China and Mongolia using an aerodynamic roughness length map derived from the POLDER/ADEOS 1 surface products, J. Geophys. Res., 110, D18S04, doi:10.1029/2004JD005013.
Laurent, B., B. Marticorena, G. Bergametti, and F. Mei (2006), Modeling mineral dust emissions from Chinese and Mongolian deserts, Global Planet. Change, 52, 121-141, doi:10.1016/j.gloplacha.2006.02.012.

Laurent, B., B. Marticorena, G. Bergametti, J. F. Léon, and N. M. Mahowald (2008), Modeling mineral dust emissions from the Sahara desert using new surface properties and soil database, J. Geophys. Res., 113, D14218, doi:10.1029/2007JD009484.

Lebel, T., and A. Ali (2009), Recent trends in the Central and Western Sahel rainfall regime $(1990-2007), J$. Hydrol., 375(1-2), 52-64, doi:10.1016/j.jhydrol.2008.11.030.

Le Houerou, H. N. (1989), The Grazing Land Ecosystems of the African Sahel, 292 pp., Springer, Berlin.

López, M. V., R. Gracia, and J. L. Arrue (2000), Effects of reduced tillage on soil surface properties affecting wind erosion in semi arid fallow lands of Central Aragon, Eur. J. Agron., 12, 191-199, doi:10.1016/S1161-0301(00) 00046-0.

Lo Seen, D., E. Mougin, S. Rambal, A. Gaston, and P. Hiernaux (1995), A regional sahelian grassland model to be coupled with multispectral satellite data. II: Toward the control of its simulations by remotely sensed indices, Remote Sens. Environ., 52, 194-206, doi:10.1016/0034-4257(94) 00127-9.

Lu, H., and Y. Shao (1999), A new model for dust emission by saltation bombardment, J. Geophys. Res., 104, 16,827-16,842, doi:10.1029/ 1999JD900169.

MacKinnon, D. J., G. D. Clow, R. K. Tigges, R. L. Reynolds, and P. S. Chavez Jr. (2004), Comparison of aerodynamically and model-derived roughness lengths $\left(\mathrm{z}_{\mathrm{o}}\right)$ over diverse surfaces, central Mojave Desert, California, USA, Geomorphology, 63, 103-113, doi:10.1016/j.geomorph.2004. 03.009 .

Mahowald, N. M., G. D. Rivera Rivera, and C. Luo (2004), Comment on "Relative importance of climate and land use in determining present and future global soil dust emission" by I. Tegen et al., Geophys. Res. Lett., 31, L24105, doi:10.1029/2004GL021272.

Mahowald, N., et al. (2008), Global distribution of atmospheric phosphorus sources, concentrations and deposition rates, and anthropogenic impacts, Global Biogeochem. Cycles, 22, GB4026, doi:10.1029/2008GB003240.

Marticorena, B., and G. Bergametti (1995), Modeling the atmospheric dust cycle: 1. Design of a soil derived dust production scheme, J. Geophys. Res., 100, 16,415-16,430, doi:10.1029/95JD00690.

Marticorena, B., G. Bergametti, B. Aumont, Y. Callot, C. N'Doumé, and M. Legrand (1997a), Modeling the atmospheric dust cycle: 2 . Simulations of Saharan dust sources, J. Geophys. Res., 102, 4387-4404, doi:10.1029/ 96JD02964.

Marticorena, B., G. Bergametti, D. A. Gillette, and J. Belnap (1997b), Factors controlling threshold friction velocity in semiarid and arid areas of the United States, J. Geophys. Res., 102, 23,277-23,287, doi:10.1029/97JD01303.

Marticorena, B., P. Chazette, G. Bergametti, F. Dulac, and M. Legrand (2004), Mapping the aerodynamic roughness length of desert surfaces from the POLDER/ADEOS bi-directional reflectance product, Int. J. Remote Sens., 25, 603-626, doi:10.1080/0143116031000116976.

Marticorena, B., et al. (2006), Surface and aerodynamic roughness in arid and semiarid areas and their relation to radar backscatter coefficient, J. Geophys. Res., 111, F03017, doi:10.1029/2006JF000462.

Marticorena, B., B. Chatenet, J. L. Rajot, S. Traoré, M. Coulibaly, A. Diallo, I. Koné, A. Maman, T. N. Diaye, and A. Zakou (2010), Temporal variability of mineral dust concentrations over West Africa: Analyses of a pluriannual monitoring from the AMMA Sahelian Dust Transect, Atmos. Chem. Phys., 10, 8899-8915, doi:10.5194/acp-10-8899-2010.

Mbourou, G. N., J. Bertrand, M. Legrand, and J. Baudet (1994), Temporal and spatial variations of the atmospheric dust loading throughout West Africa over the last thirty years, Ann. Geophys., 12, 265-273, doi:10.1007/s00585-994-0265-3.

Mbourou, G. N., J. J. Bertrand, and S. E. Nicholson (1997), The diurnal and seasonal cycle of wind-borne dust over Africa north of the equator, J. Appl. Meteorol., 36, 868-882, doi:10.1175/1520-0450(1997)036<0868: TDASCO $>2.0 . \mathrm{CO} ; 2$.

Menut, L. (2008), Sensitivity of hourly Saharan dust emissions to NCEP and ECMWF modeled wind speed, J. Geophys. Res., 113, D16201, doi:10.1029/2007JD009522.

Middleton, N. J., and A. S. Goudie (2001), Saharan dust: sources and trajectories, Trans. Inst. Br. Geogr., 26, 165-181, doi:10.1111/1475-5661.00013. Minvielle, F., B. Marticorena, D. A. Gillette, R. Lawson, R. Thompson, and G. Bergametti (2003), Relationship between the aerodynamic roughness length and the roughness density in cases of low roughness density, Environ. Fluid Mech., 3, 249-267, doi:10.1023/A:1022830119554.

Mougin, E., D. Lo Seen, S. Rambal, A. Gaston, and P. Hiernaux (1995), A regional Sahelian grassland model to be coupled with multispectral satellite data. I: Model description and validation, Remote Sens. Environ., 52, 181-193, doi:10.1016/0034-4257(94)00126-8. 
Mougin, E., et al. (2009a), The AMMA Gourma observatory site in Mali: Relating climatic variations to changes in vegetation, surface hydrology, fluxes and natural resources, J. Hydrol., 375(1-2), 14-33, doi:10.1016/ j.jhydrol.2009.06.045.

Mougin, E., V. Demarez, M. Grippa, P. Hiernaux, L. Larouzière, C. Lion, M. Diawara, and N. Soumaguel (2009b), Evaluation of MODIS LAI products in a Sahelian environment (Gourma, Mali), poster presented at 4th Global Vegetation Workshop, Univ. of Mont., Missoula.

Moulin, C., et al. (1998), Satellite climatology of African dust transport in the Mediterranean atmosphere, J. Geophys. Res., 103, 13,137-13,144, doi:10.1029/98JD00171.

Myneni, R. B., et al. (2002), Global products of vegetation leaf area and fraction absorbed PAR from year one of MODIS data, Remote Sens. Environ., 83, 214-231, doi:10.1016/S0034-4257(02)00074-3.

Petit-Maire, N., J. C. Celles, D. Commelin, G. Delibrias and M. Raimbault (1983), The Sahara in northern Mali: Man and his environment between 10,000 and 3500 years bp. (Preliminary results), Afr. Archeol. Rev., 1, $105-125$.

Pierre, C., G. Bergametti, B. Marticorena, E. Mougin, T. Lebel, and A. Al (2011), Pluriannual comparisons of satellite-based rainfall products over the Sahelian belt for seasonal vegetation modeling, J. Geophys. Res., 116, D18201, doi:10.1029/2011JD016115.

Priestley, C. H. B. (1959), Turbulent Transfer in the Lower Atmosphere, 130 pp., Univ. of Chicago Press, Chicago, Ill.

Prospero, J. M., P. Ginoux, O. Torres, S. E. Nicholson, and T. E. Gill (2002), Environmental characterization of global sources of atmospheric soil dust identified with the Nimbus 7 Total Ozone Mapping Spectrometer (TOMS) absorbing aerosol product, Rev. Geophys., 40(1), 1002, doi:10.1029/2000RG000095.

Rajot, J. L. (2001), Wind blown sediment mass budget of Sahelian village land units in Niger, Bull. Soc. Geol. Fr., 172, 523-531, doi:10.2113/ 172.5.523.

Roberts, G., M. J. Wooster, and E. Lagoudakis (2008), Annual and diurnal African biomass burning temporal dynamics, Biogeosciences, 5, 3623-3663, doi:10.5194/bgd-5-3623-2008.

Roujean, J. L., M. Leroy, and P. Y. Deschamps (1992), A bidirectional reflectance model of the Earth's surface for the correction of remote sensing data, J. Geophys. Res., 97(D18), 20,455-20,468, doi:10.1029/92JD01411.

Schmechtig, C., B. Marticorena, B. Chatenet, G. Bergametti, J. L. Rajot, and A. Coman (2011), Simulation of the mineral dust content over western Africa with the CHIMERE-DUST model from the event to the annual scale, Atmos. Chem. Phys., 11, 7185-7207, doi:10.5194/acp-11-7185-2011.

Sokolik, I. N., and O. B. Toon (1999), Incorporation of the mineralogical composition into models of the radiative properties of mineral aerosol from UV to IR wavelengths, J. Geophys. Res., 104(D8), 9423-9444 doi:10.1029/1998JD200048.

Stroppiana, D., P. A. Brivio, J.-M. Gregoire, C. Liousse, B. Guillaume, C. Granier, A. Mieville, M. Chin, and G. Petron (2010), Comparison of global inventories of $\mathrm{CO}$ emissions from biomass burning derived from remotely sensed data, Atmos. Chem. Phys., 10, 12,173-12,189, doi:10.5194/acp-10-12173-2010.

Tanaka, T. Y., and M. Chiba (2006), A numerical study of the contributions of dust source regions to the global dust budget, Global Planet. Change, 52, 88-104, doi:10.1016/j.gloplacha.2006.02.002.

Tegen, I., and I. Fung (1995), Contribution to the atmospheric mineral load from land surface modification, J. Geophys. Res., 100(D9), 18,707-18,726, doi:10.1029/95JD02051.

Tegen, I., M. Werner, S. P. Harrison, and K. E. Kohfeld (2004), Relative importance of climate and land use in determining present and future global soil dust emission, Geophys. Res. Lett., 31, L05105, doi:10.1029/ 2003GL019216.

Tidjani, A. D. (2008), Erosion éolienne dans le Damagaram est (sud-est du Niger): paramétrisation, quantification et moyens de lutte, Doctorat en sciences agronomiques et ingénierie biologique, 133 pp., Univ. Cath. Louvain, Louvain, Belgium.

Torres, O., P. K. Bhartia, J. R. Herman, Z. Ahmad, and J. Gleason (1998), Derivation of aerosol properties from satellite measurements of backscattered ultraviolet radiation: Theoretical basis, J. Geophys. Res., 103, 17,099-17,110, doi:10.1029/98JD00900.

Tracol, Y., E. Mougin, P. Hiernaux, and L. Jarlan (2006), Testing a sahelian grassland functioning model against herbage mass measurements, Ecol. Modell., 193, 437-446, doi:10.1016/j.ecolmodel.2005.08.033.

Wang, Y., A. F. Stein, R. R. Draxler, J. D. De la Rosa, and X. Zhang (2011), Global sand and dust storms in 2008: Observation and HYSPLIT model verification, Atmos. Environ., 45, 6368-6381, doi:10.1016/j. atmosenv.2011.08.035.

White, B. R. (1979), Soil transport by wind on Mars, J. Geophys. Res., 84, 4643-4651, doi:10.1029/JB084iB09p04643.

Yoshioka, M., N. Mahowald, J.-L. Dufresne, and C. Luo (2005), Simulation of absorbing aerosol indices for African dust, J. Geophys. Res., 110, D18S17, doi:10.1029/2004JD005276.

Zender, C. S., and E. Y. Kwon (2005), Regional contrasts in dust emission responses to climate, J. Geophys. Res., 110, D13201, doi:10.1029/ 2004JD005501.

G. Bergametti, B. Marticorena, and C. Schmechtig, Laboratoire Interuniversitaire des Systèmes Atmosphériques, 61 Avenue du General de Gaulle, F-94000 Créteil, France. (gilles.bergametti@lisa.u-pec.fr; beatrice.marticorena@lisa.u-pec.fr; catherine.schmechtig@lisa.u-pec.fr)

C. Bouet, Biogéochimie et Écologie des Milieux Continentaux, 32 Avenue Henri Varagnat, F-93143 Bondy CEDEX, France. (christel.bouet@ird.fr)

E. Mougin and C. Pierre, Geosciences Environnement Toulouse, 14 Avenue Edouard Belin, F-31000 Toulouse, France. (caroline.pierre@get. obs-mip.fr; eric.mougin@get.obs-mip.fr) 